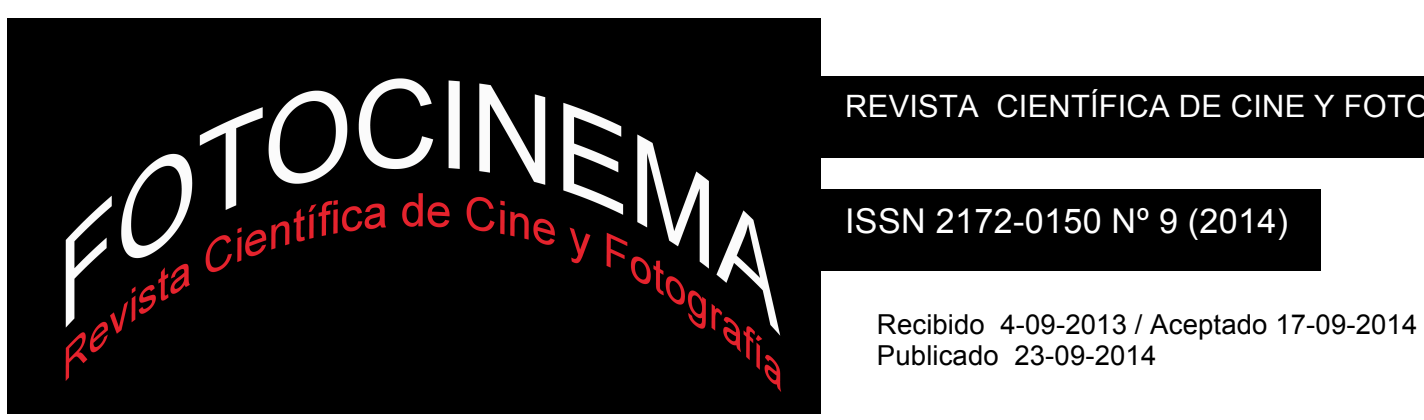

\title{
INTERTEXTUALIDAD EN LA PIEL QUE HABITO: PINTURA, ESCULTURA Y DIBUJO
}

\section{INTERTEXTUALITY IN THE SKIN I LIVE IN: PAINTING, SCULPTURE AND DRAW}

\author{
Marina Parés Pulido \\ Paris X (Université Paris Ouest Nanterre la Défense) \\ m.pares@hotmail.es
}

\section{Resumen:}

El presente artículo tiene como objetivo estudiar las relaciones de intertextualidad existentes en $L a$ piel que habito. El juego de citas a un conjunto de obras de arte (literarias, fílmicas y plásticas) que ya venía realizando Almodóvar en sus obras anteriores, especialmente a partir de La flor de mi secreto, encuentra su culmen en la penúltima película del director manchego, pues en este caso, la trama está envuelta al completo por todo un tejido de referencias.

De entre todas éstas, las citas a las artes plásticas (escultura y pintura) tienen un lugar esencial en el film, cumpliendo una función tautológica con respecto a la trama: en especial, la obra de la artista francesa Louise Bourgeois.

Para poder explorar a fondo esta red intertexual se procederá a hacer un análisis de tipo semiótico-textual, en el que se combina la descripción de las imágenes con una interpretación de, en este caso, las obras artísticas que aparecen citadas de forma explícita o implícita a lo largo del film.

\begin{abstract}
:
The present article seeks to study the intertextual relations appearing in The skin I live in. This game of quotes to a conjoint of pieces of arts (whether literary, filmic or plastic arts) that Almodóvar had already been making in his lasts works, specially from La flor de mi secreto on, finds its culmination in the nextto-last film of this director because the whole plot is wrapped in these kind of references.

Among these, the quotes to plastic arts (considering as such sculpture and painting) have a relevant place in the film, accomplishing a tautological function in relation to the plot: specially, the work of French artist Louise Bourgeois.

In order to explore this intertextual net, a semiotic-textual analysis will be done, combining both descriptions of images and the interpretation of the pieces of art appearing explicitly or implicitly in The skin I live in.
\end{abstract}

Palabras clave: Intertextualidad; La Piel que habito; Almodóvar; Bourgeois; pintura; escultura.

Keywords: Intertextuality; The skin I live in; Almodóvar; Bourgeois; Painting; Sculpture. 


\section{Introducción}

Desde sus comienzos en los años ochenta en la Movida madrileña, Almodóvar ha abierto su propio camino en el cine, filmando 19 largometrajes hasta la fecha de muy diversa índole. Sin embargo, pese a haber pasado de una estética underground en sus orígenes (Pepi Luci Bom y otras chicas del montón, 1980) a un cine que la crítica ha querido bautizar como "más maduro" o, al menos, más poético, como Hable con ella (2002), su trayectoria sigue una línea coherente. Nos encontramos ante un universo propio de un cine de autor, que reúne entre otras, las siguientes características:

Interrogación sobre el cuerpo, la sexualidad y el deseo.

Búsqueda de género propio, que pasa por el melodrama, la comedia, el thriller y el cine folclórico.

Hibridación e injertos de otras obras, creando todo un entramado de referencias.

En este contexto, La piel que habito aparece como una película clave: no solo se trata la identidad sexual del individuo, sino la alteración del cuerpo de un personaje en contra de su propia voluntad, volviéndolo una especie de híbrido. Pero no solo se trata la hibridación desde este punto de vista, sino también desde el de los géneros (¿̇se trata de un thriller, de "una historia de venganza" como manifiesta Almodóvar; de un drama?) y desde el de las citas, tanto cinematográficas como a otras artes. Es decir, se trata de una película que es más bien un mosaico narrativo, en el que todas las piezas (consideradas como tal tanto los elementos narrativos -personajes e historia-, como diegéticos, en un sentido más amplio -referencias directas-) irán encajando conforme el tiempo vaya discurriendo entre los metros de la cinta. Como señala Poyato (2014, p. 12), se trata de una "cinematografía [...] cuya escritura se elabora en gran medida a partir de operaciones de transtextualidad que [...] encuentra[n] un eco en la diégesis interesada por operaciones de transplante, transexualidad y transgénesis, lo que demuestra un interés enunciativo por el cuerpo y sus mutaciones [...]”. 


\section{Objetivos}

En este análisis de La piel que habito se estudiarán, de entre todas las referencias (que van desde Mygale, la novela de Jonquet en la que está basada, hasta todo un elenco de citas cinematográficas, como Les yeux sans visage, de Franju), aquéllas relacionadas con las artes plásticas.

$\mathrm{Al}$ igual que sucede en otras películas anteriores, el discurso de La piel que habito queda enriquecido con las referencias al arte pictórico que se van sucediendo a lo largo de sus fotogramas. Así, por ejemplo, en Carne trémula (1997) aparece la Danae de Tiziano o en Los abrazos rotos (2009), el personaje de Ernesto Martel es un coleccionista de arte.

Como señala Navarrete-Galiano (2012, p. 76), en la obra de Pedro Almodóvar esto "se plantea de cuatro formas que se agrupan en dos vertientes:

Incorpora cuadros (pinturas ya conocidas, en los espacios donde se desarrollan sus películas) y plantea la creación de nuevos cuadros para sus títulos de créditos o carteles.

Crea nueva pintura, por un lado la recreación de cuadros conocidos, [...] tableaux vivants y por otro, origina nuevas pinturas influidas por pintores (abstracción; realismo) por medio de la técnica o la sintaxis fílmica."

En otras ocasiones no solo se limita al arte pictórico, sino que también incluye referencias a figuras escultóricas. Este mismo autor destaca la figura de La piedad que acaba por ser recreada en La ley del deseo (1987).

En este sentido, en La piel que habito no solo la pintura, sino que también la escultura tiene un papel fundamental a través de la obra de Louise Bourgeois, tal y como se verá a continuación.

\section{Metodología y marco teórico}

Almodóvar quizá sea el autor español que, a excepción de Buñuel, más literatura ha generado en torno a su figura y a su forma de hacer cine. En lo que respecta a La piel que habito cabe destacar que debido a lo reciente de la 
película (2011), aún no ha habido tiempo de generar una amplia literatura científica. Sin embargo, ésta está lejos de ser inexistente, lo que indica su relevancia en la trayectoria del cineasta. Para este análisis se ha recurrido principalmente, de entre toda ésta, a un artículo llevado a cabo por Thibaudeau en 2013: El cuerpo, la piel y la pantalla: los territorios habitados por Pedro Almodóvar que trata precisamente sobre el juego que se da entre la pantalla y el cuerpo y la piel como proyecciones del yo-interno, y que ampliará en otro del mismo año "Esperando a Vera: la metamorfosis del sujeto en La piel que habito de Pedro Almodóvar" (Thibaudeau, 2013a); y La piel que habito: nueva creación literaria, pictórica y escultórica de Almodóvar (2012), de Navarrete-Galiano, que hace referencia a las obras de éste carácter que aparecen en el film.

En cuanto a la metodología seguida y siguiendo a lo expuesto por Aumont un film

puede ser considerado desde un punto de vista tecnológico, en tanto que soporte físico-químico [...] desde un punto de vista económico, como conjunto de copias [...], desde un punto de vista temático, realizando un análisis de contenido [...] como documento relevante de la sociología de la recepción [...] (2012, p. 144).

A estas categorías Aumont añade una última, consistente más bien en el ángulo elegido: se trata del análisis textual fílmico. Por su parte, Christian Metz (1971) señalaba que existen dos tipos de conjuntos de códigos: "los conjuntos concretos o mensajes fílmicos y los conjuntos construidos por el analista, los códigos; los mensajes fílmicos son igualmente llamados como “textos" (Aumont, 2012, p. 143).

De esta manera, podría decirse que lo que se elabora haciendo un análisis es todo un entramado de códigos que denomina como "sistema del film” y que, en términos barthesianos (referidos a la literatura) se corresponde con la noción de "texto"1. Para Metz, estos códigos pueden ser más o menos

\footnotetext{
${ }^{1}$ Aumont señala a este respecto la dificultad, precisamente, que encuentra este sistema de códigos para realizar un análisis fílmico, ya que ha de transponer la imagen en palabras. Así "la estrategia de escritura de un análisis fílmico debe esforzarse en realizar un difícil equilibrio entre el comentario crítico $[\ldots]$ y $[\ldots]$ citaciones fílmicas [...] utilizando [...] todos los recursos de la maquetación [...] y
} 
universales (algunos pudiendo ser aplicados solo en un número reducido de películas) pero que no llegan nunca a ser particulares de un film. En cambio, hay otro sistema que sí es singular: el "texto", que es el film en sí mismo (o cualquier medio de expresión que sea significante). Es decir, la sucesión de la banda imagen y de la banda sonido que percibe un espectador (para Barthes, esto se corresponde con la "obra").

Por otro lado, cabe destacar que la teoría moderna del texto "basta con que haya un desbordamiento significante para que haya texto [...] No considera la obra como simples mensajes, o incluso de enunciados, como productos acabados, pero como "producciones perpetuas, enunciaciones a través de las cuales el sujeto continúa debatiéndose" (Aumont, 2012, p. 149).

Partiendo de esta base, puede decirse entonces que el espectador (o analista) construye, en igualdad de condiciones, la obra mientras realiza su lectura pues es quien interpreta de alguna manera las imágenes que desfilan ante sus ojos. Y, este "significado del mensaje cambia según el código elegido para interpretarlo" (Eco, 1999, p. 79).

De esta manera, en el análisis ofrecido a continuación se realizará una lectura interpretativa de aquellas citas y referencias pictóricas y escultóricas propuestas por Almodóvar en La piel que habito, acompañándolas de un comentario de carácter descriptivo.

Cabe decir, por otro lado, que la aproximación de tipo semiológica escogida para realizar este análisis trata de estudiar "el sistema propio de un film [...] no como figura del lenguaje cinematográfico sino en relación a otras configuraciones significantes de la obra en el mismo film y el sentido que éstas engendran" (Aumont, 2012, p. 144). Así, no pretende ser una muestra de un tipo de código cinematográfico presente en un conjunto de películas, sino que es un estudio de un caso particular no extrapolable.

También se ha recurrido al concepto que Génette bautizó como "intertextualidad" en su obra Palimpsestos, una categoría englobada a su vez en el término más amplio de transtextualidad y que queda definida como 
"una relación de co-presencia entre dos o más textos, es decir, eidéticamente y frecuentemente, por la presencia efectiva de un texto en otro" (Genette, 1982, p. 8).

\section{La obra de Louise Bourgeois}

Como se venía exponiendo, la obra de esta artista francesa resulta fundamental en La piel que habito. Ésta se inscribe en lo que se podrían considerar tres aspectos diferentes; por un lado, en lo puramente visual, en la presencia física de sus trabajos. Por otro lado, si bien no pueden considerarse como "tableaux-vivant" ya que se trata de una serie de esculturas, la inspiración en éstas para llevar a cabo la puesta en escena. Y, finalmente, la relación que ésta guarda con la propia trama de la película, enfatizando su discurso.

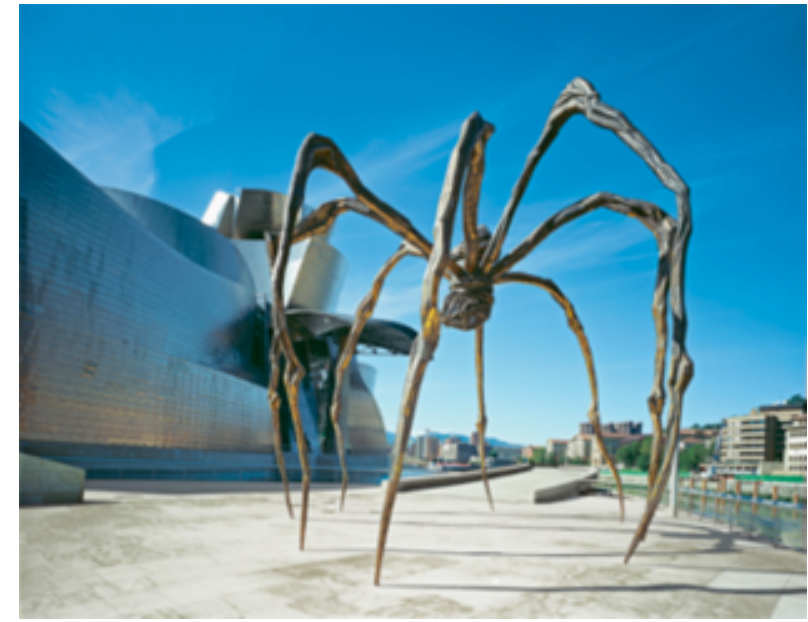

Maman (1999), L. Bourgeois

Para comenzar, se podría señalar lo que no parece ser más que una coincidencia del título de la novela en la que se basa la película (Tarántula) con Maman (1999), una escultura de casi 9 metros de alto, en la que se pone de manifiesto la visión de Bourgeoise sobre el doble carácter de la maternidad: protección $\mathrm{y}$

depredación, fortaleza y fragilidad (Museo Guggenheim de Bilbao). Aunque esto no parece ser más que una coincidencia, el personaje de Vera muestra estas dualidades.

En cualquier caso desde prácticamente el principio de la película la obra de Bourgeois se hace patente: tras los planos de situación de El cigarral con los que se abre el film y la imagen de Vera, que hace yoga tras un doble encierro (la ventana y las rejas que se superponen a ésta), llega un travelling en el que ya se ve a la protagonista por completo, vestida con una malla de color carne. 
Acto seguido, se pasa a otro plano mucho más cerrado, que recorre con otro travelling el cuerpo de Vera, completamente estirado sobre el sofá, en una postura muy similar a la anterior. Sus brazos quedan suspendidos por encima de la cabeza, cayendo ligeramente hacia abajo.

Esta posición recuerda a la que presenta, por un lado, la figura del cuerpo sin cabeza de Arch of Hysteria (1993), pero también al de Celda: arco de histeria (1992-1993).

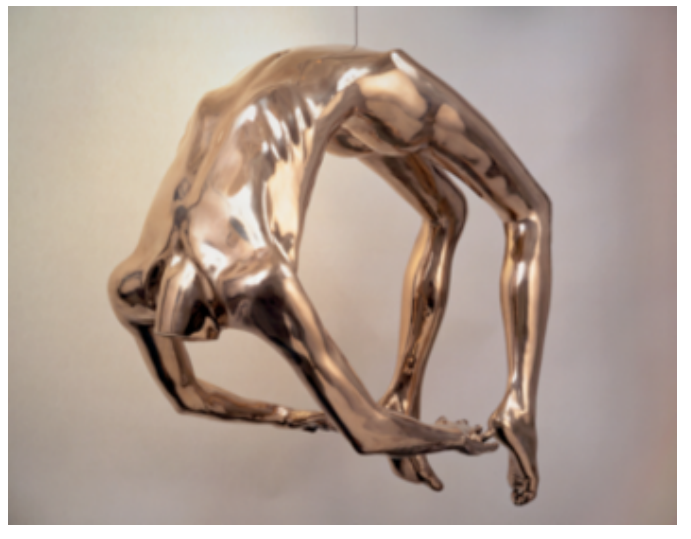

Arch of Hysteria(1993), L. Bourgeois
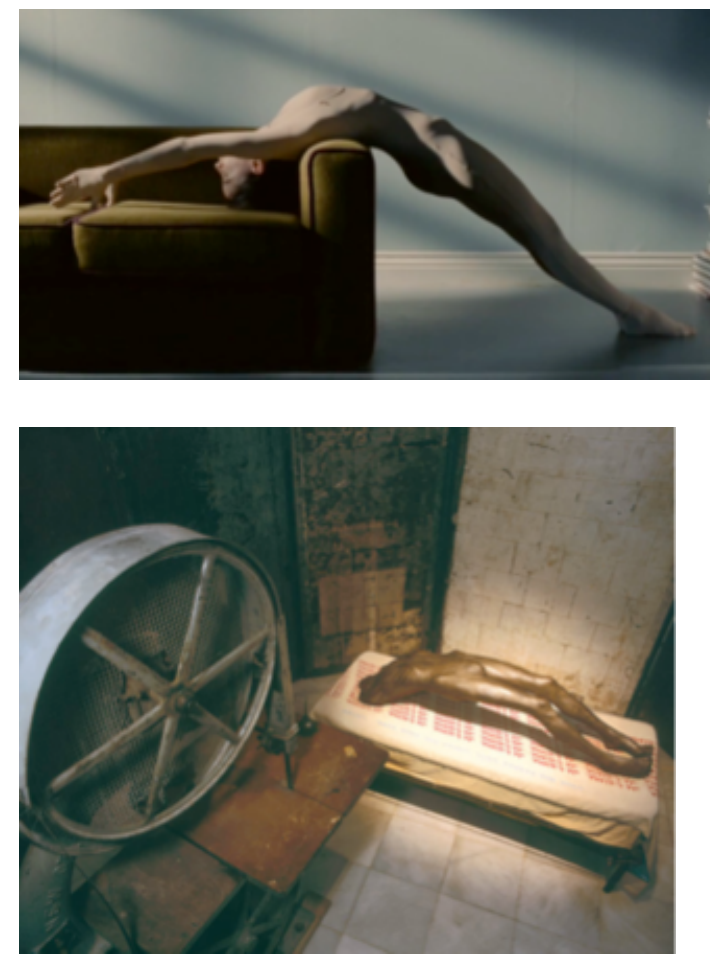

Celda: arco de histeria (1992-93), L. Bourgeois

En esta instalación, el cuerpo se contorsiona sobre una cama, cuyo colchón está cubierto con una sábana pintada con una serie de “Je t'aime”. El entorno de Vera frente al de la escultura cambia notablemente: mientras que la primera está en una habitación completamente blanca, la segunda está rodeada de ladrillos, en tonos ocres. Pero, si bien esto es diferente, el significado es similar: ambas están prisioneras. A este respecto, Fernández Ruiz (2004, p. 215), señala que "los espacios-habitación producen una intensa sensación corporal. Hay una presencia perturbadora del cuerpo, es a él al que remiten las cosas más diversas”, tal y como sucede en el cuarto de Vera. Todo remite a ella, a su situación, a su encierro. Así, pasados unos minutos de la película, hay un plano general de toda la habitación, tras la primera discusión entre Ledgard y ella. Las paredes grises, llenas de dibujos, 
se contraponen a la colcha roja, situada en el centro y llamando visiblemente la atención. Encima de ésta, está sentada Vera con la malla de color carne, mientras que Ledgard se levanta, quedando diluido su traje gris con el suelo, del mismo color: es el cuerpo de ella, al igual que sucede en la obra de Bourgeois, lo que llama la atención.

En la habitación también se encuentran otros elementos que recuerdan a la obra de la artista: en las esquinas pueden verse una serie de pelotas recubiertas de retales de tela que se asemejan a aquélla que se ve en el catálogo de Bourgeois que Vera hojea.
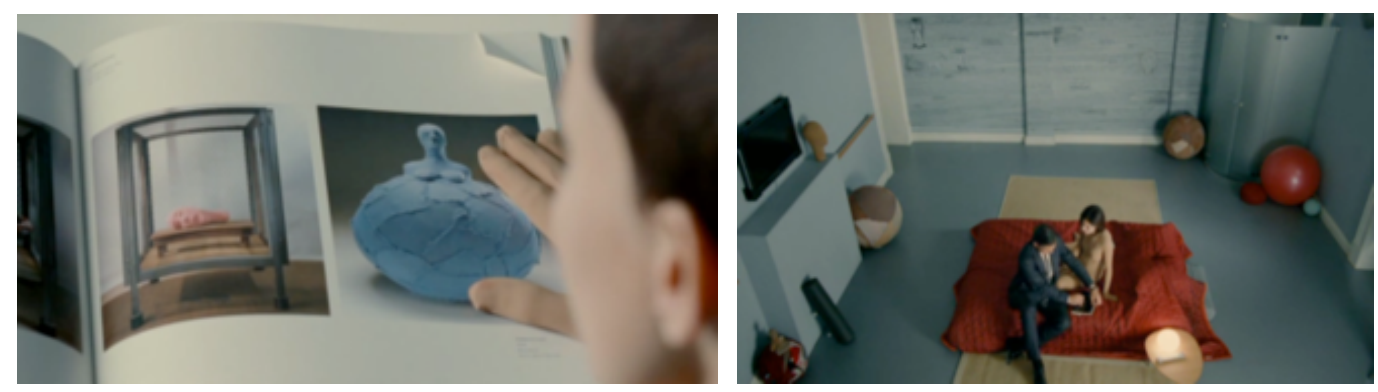

A la izquierda puede verse el catálogo de Bourgeois, en el que aparece el mismo tipo de pelota que habrá en el cuarto de Vera (imagen derecha).

Obra que también se hace eco de una de las citas de Bourgeois y que bien podría encajar con la trama de la película: "Mi feminidad está roída por las ratas. Roída por dentro y por fuera como un huevo agujereado con un alfiler y luego sorbido hasta vaciarlo. Hay que fortificarla, reforzarla, hacerla como una pelota de espuma que rebota hasta el techo" (en RTVE.es, el $18 / 10 / 2012)^{2}$.

Aplicada a la película, da pie a cuestionarse aún más sobre la irónica feminidad de Vicente/Vera, pues la suya no sólo es que esté vacía o que sea un cuerpo exterior que represente aquello que hay en su interior, sino que, precisamente no es elegida, le ha sido impuesta.

Al lado de esta pelota, sobre la cual se encuentra el busto de una mujer, puede verse en el catálogo la otra obra que aparece en la habitación de Vera: se trata de una cara tumbada sobre una mesa, encerrada. Aunque no sean

\footnotetext{
2 Disponible en: http://www.rtve.es/noticias/20121018/louise-bourgeois-exorciza-temores-granmuestra/570908.shtml
} 
idénticos, recuerda a la cabeza sin rostro que hay al lado de la televisión (como puede verse en los dos fotogramas incluidos anteriormente).

Hay que destacar aquí que la obra de Bourgeois no queda presentada en la película de una forma en la que solo los espectadores que conozcan su obra puedan reconocerla: es la propia Vera quien ve un documental sobre ella en su encierro y quien se siente identificada con su trabajo, imitándola.

De esta forma, justo después de ver cómo ésta se acerca más y más a la pantalla que le permite observar las figuras, la siguiente vez que Vera aparezca será en un plano muy cerrado, que recoge sus manos abriendo un catálogo de, como se puede leer claramente, Louise Bourgeois. Al abrirlo, lo dejará abierto por la página que contiene las dos obras comentadas anteriormente.

La cámara, con un travelling horizontal, que pasa del catálogo a Vera, y de Vera a su derecha, muestra cómo ésta pega una especie de goma sobre un busto cuyo rostro solo está esbozado, fijándose en el catálogo.

Este mismo libro será mostrado al principio de la película, en un travelling muy similar: tras haber visto a Vera haciendo yoga, se ve el nombre de

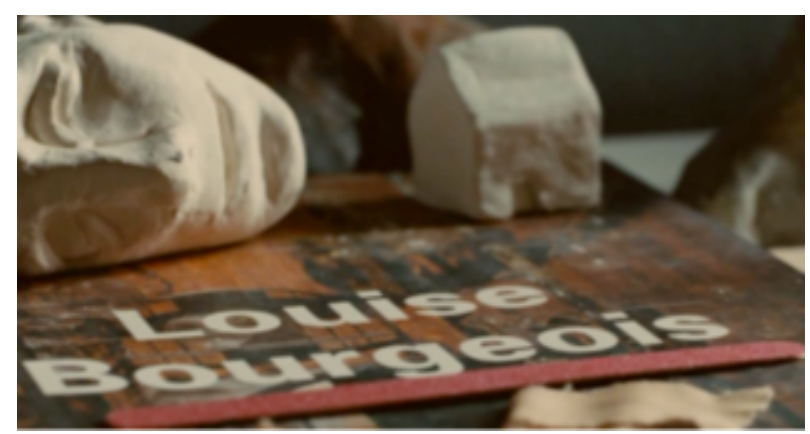
"Louise Bourgeois" ocupando casi la totalidad de la pantalla. Encima de éste, están tanto una cabeza tumbada como una casa (muy similar a las dibujadas en la colección de mujeres-casa). Conforme el travelling avanza, se van descubriendo más obras que Vera ha hecho a imitación de la artista: una serie de bustos entrelazados, una vez más sin ningún rostro que les defina (al igual que la parte superior de Seven in bed, 2007) y otros tres más, cubiertos por retales y sobre uno de los cuales Vera trabaja, cortando y pegando trozos de la misma tela que su malla. 


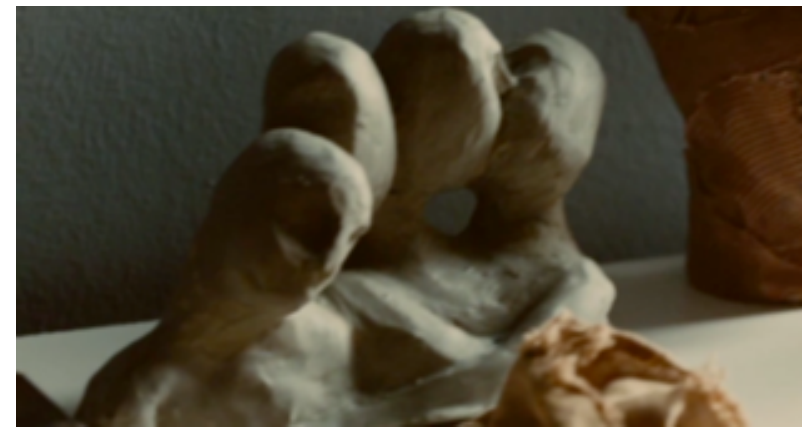

Bustos hechos por Vera

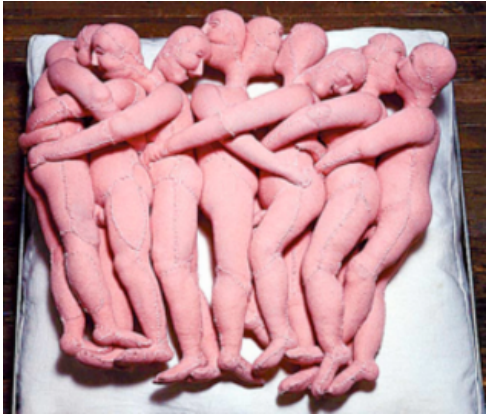

Seven in bed (2007), L. Bourgeois

De hecho, la propia malla de color carne de Vera hace que ésta recuerde vagamente a los cuerpos de la obra de la escultora francesa. Por un lado, por el color, pues es lo que hace que se identifique con la piel humana ${ }^{3} \mathrm{y}$, en la obra de Bourgeois es el rosa "el que evoca el cuerpo humano, la intimidad" (Fernández Ruiz, 2004, p. 207). Por otro, por las costuras claramente visibles de la malla, que marcan la cremallera de la espalda y la forma de los omoplatos y pechos (que también se presentan lisos y sin pezones), y que recuerdan ligeramente a los parches habituales en las figuras de Bourgeois. Al igual que sucede con la piel nueva de Vera, pues sus cicatrices que parchean la totalidad de su cuerpo, dividiéndolo en secciones que son superpuestas al cuerpo que Vera/Vicente siente como verdadero: el suyo propio.

Pero, aún antes de esta escena, el cuerpo de Vera aparece ya dividido en secciones debido a las marcas de la cirugía estética que traza el doctor Ledgard. Sobre estas zonas, el doctor pondrá retales (una vez más) de piel sintética nueva, como anteriormente había estado practicando con un maniquí.

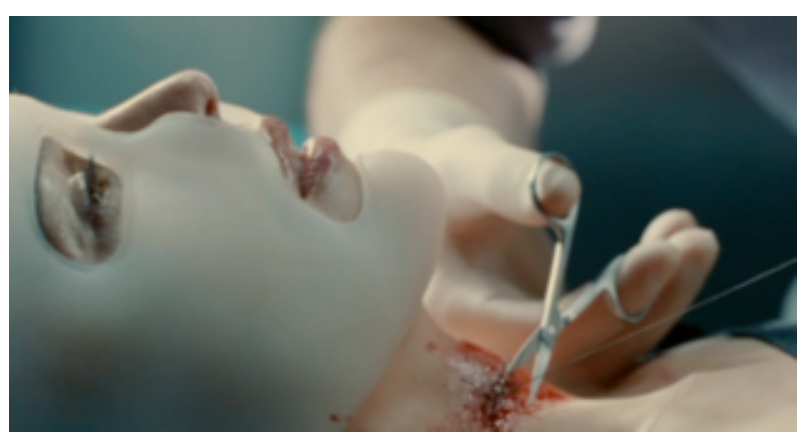

Yendo aún más allá, hay una última referencia al trabajo de costura en relación a Vera: al igual que ella hace con sus figurines, el doctor Ledgard le

\footnotetext{
${ }^{3}$ A este respecto, Thibaudeau $(2013,197)$ comenta que "la piel es la primera ropa del cuerpo así como cualquier vestimenta es una segunda piel, como explicita el body carne llevado por Vera".
} 
cose el cuello con aguja e hilo cuando ella intenta degollarse, tras el infructuoso intento de huida. Intento que tiene lugar en la escalera, cuyas lámparas en forma circular recuerdan ligeramente a las presentes en Precious Lyquid (1999).

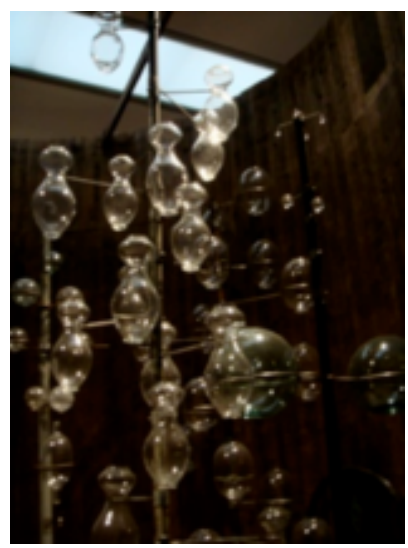

Precious Lyquid (1999), L. Bourgeois

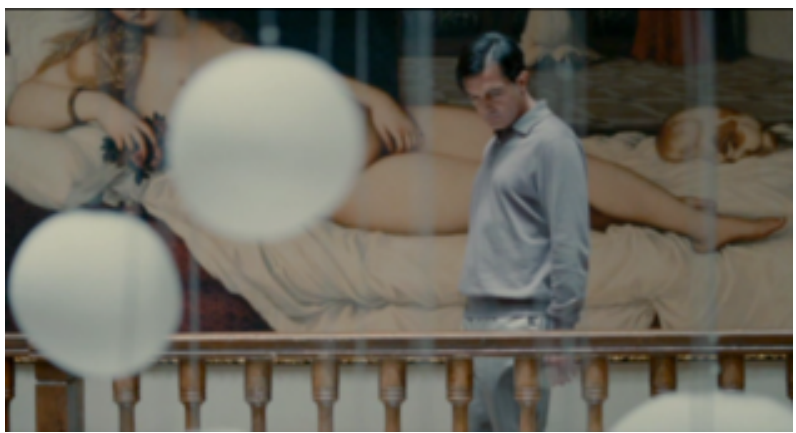

Lámparas de la mansión de Ledgard

Siguiendo a lo señalado por Thibaudeau (2013, p. 197), esta referencia a la costura, a la que se le reserva un plano detalle, no es en absoluto banal. Es la afirmación, una vez más, de que Vera es el resultado de haber unido trozos de piel, un trabajo de corte y confección.

La costura-tejido estará presente en varias partes de la película: para comenzar, Vicente trabaja en una tienda de ropa vintage. Su primera aparición pues será arreglando un maniquí (que se trata de un muñeco de paja sin rostro) con un vestido amarillo cuyas costuras son visibles. Poco después, se verá a Vicente cosiendo retales de diferentes colores sobre otro maniquí, siguiendo los mismos gestos que hará como Vera al fabricar los bustos inspirados en Bourgeois. Para concluir, será precisamente un vestido lo que permitirá que Vera sea reconocida como Vicente por parte de Cristina y de su madre. 4

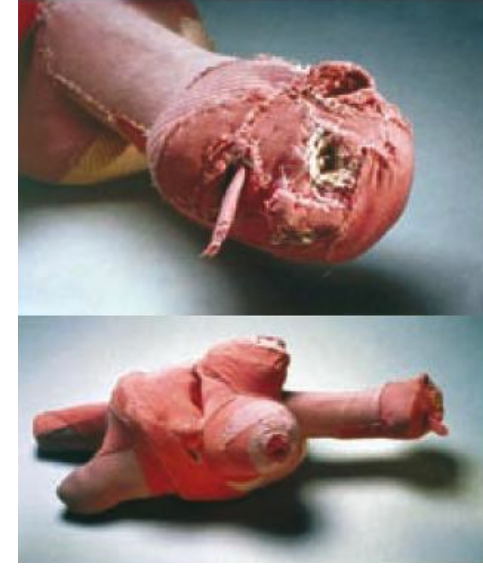

Acolchado (1999) de L. Bourgeois

\footnotetext{
${ }^{4}$ Cabe destacar también, en esta analogía de la vestimenta como una segunda piel, la venta de la ropa que realiza el personaje interpretado por Agustín Almodóvar de su mujer a modo de venganza.
} 
Pero volviendo a esta forma de concebir el cuerpo como un conjunto de retales, Fernández Ruiz (2004, pp. 207-208) señala a propósito de Acolchado (1999) que "es una muñeca de trapo sufriente que parece herida y vendada, o mutilada y en carne viva [...] Es a la vez víctima y agresora”. Algo que parece casar perfectamente con la identidad de Vera: primero, es víctima (de la venganza de Ledgard y de su propio cuerpo mutilado) y, acaba, finalmente, siendo la agresora.

Por otro lado, el amalgama de piel-cuerpo que realiza Bourgeois en su obra, en el que se confunden los sexos, sin un "masculino" ni un "femenino" marcado, es donde se encuentra la máxima identificación de Vera con la obra de Bourgeois. De esta forma, siguiendo a McEvilley:

Bourgeois también ha declarado que a veces combina lo masculino y lo femenino en una imagen [...]. Esto parece corresponder a su declaración de que gran parte del tema de su obra no es sexual sino presexual. Su aura evoca a menudo el período anterior a la aparición de la distinción sexual (McEvilley, 2007, p. 344).

En la película hablar de presexualidad, entendida como la condición propia de un niño, parece fuera de lugar. Sin embargo, podría entenderse como aquella de Vera, que acaba de nacer en tanto que mujer.

Resumiendo, en este primer aspecto, tanto la obra de Almodóvar como la de Bourgeois coinciden en el deterioro del cuerpo físico, en su mutilación. Bourgeois reclama el dolor de lo femenino, Almodóvar, en un cierto sentido también (el dolor de Gal ante el desinterés de su marido y el accidente; la locura de Norma; el dolor de Marilia de no poder reconocerse como madre ante Ledgard; el dolor de la madre de Vicente por la pérdida de su hijo; y, finalmente, el de Vera, convertida en mujer en contra de su voluntad).

Como ya se ha comentado, también coinciden en la ambivalencia de los sexos, que en el fondo no es más que algo que viene determinado por la anatomía humana, recubierta de piel.

Pero, volviendo a las obras que aparecen en La piel que habito, aún queda una por nombrar y que guarda también una relación fundamental con la trama. Se trata de los dibujos que hay en la pared de Vera: una serie de 
posiciones de yoga, tres de la mujer-casa y otro con forma de cabeza, en el que hay dibujadas varias caras. En cuanto al significado de este último, viene derivado de lo comentado anteriormente: bajo un mismo rostro (Vera), se encuentran otros muchos (el de Vicente, el de la Vera que finge estar enamorada de Ledgard, el de la Vera que como Vicente quiere vengarse...).

Por otro lado, dos de las tres mujer-casa son préstamos literales, una vez más, de Bourgeois. El tercero de ellos, que muestra en lugar de una cabeza una casa con dos rejas / ventanas, también recuerda al estilo presentado por esta serie. Éste solo aparece al final, cuando Vera ha conseguido enamorar a Ledgard y vuelve a su habitación, no tanto ya como prisionera sino como habitante de la casa.

En cuanto a los otros dos, uno (el primero que realiza Vera, además), se trata de la mujer-casa esculpida por Bourgeois en 1994: tumbada, con las piernas flexionadas, unos pechos que en un primer vistazo parecen brazos y con la cabeza reemplazada por una casa dotada solo de una pequeña puerta. El otro dibujo resulta muy parecido, aunque esta vez la obra original es un lienzo, de la serie también Femme-maison (1946-1947). Aquí nos encontramos igualmente ante el cuerpo de una mujer -cuya vagina se presenta de forma frontal, destacada respecto a todo lo demás-, que tampoco tendrá brazos pero sí pechos y cuya cabeza es igualmente sustituida por un bloque de pisos, cubierto de pequeñas ventanas.
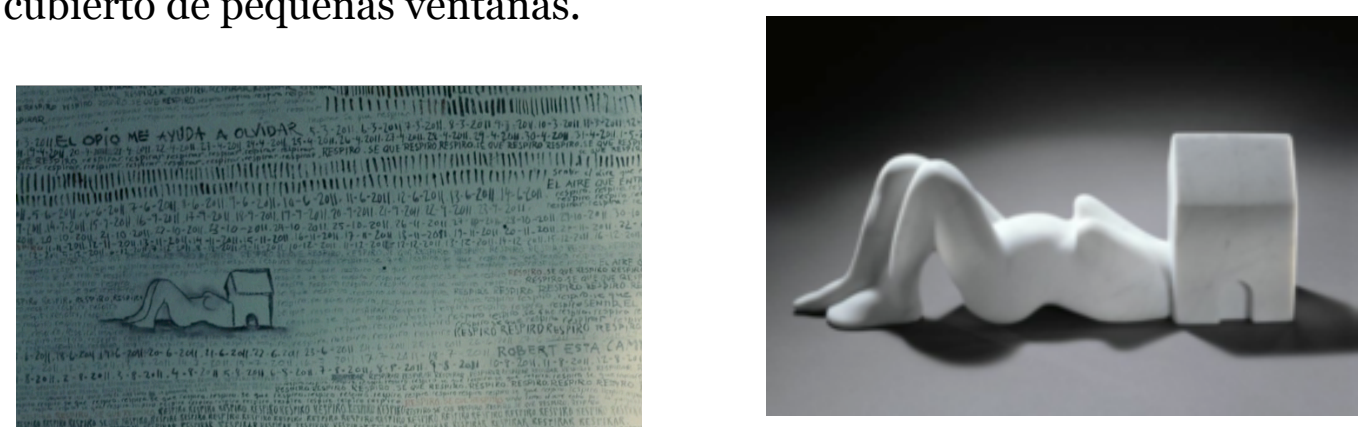

Femme-maison, L. Bourgeois 

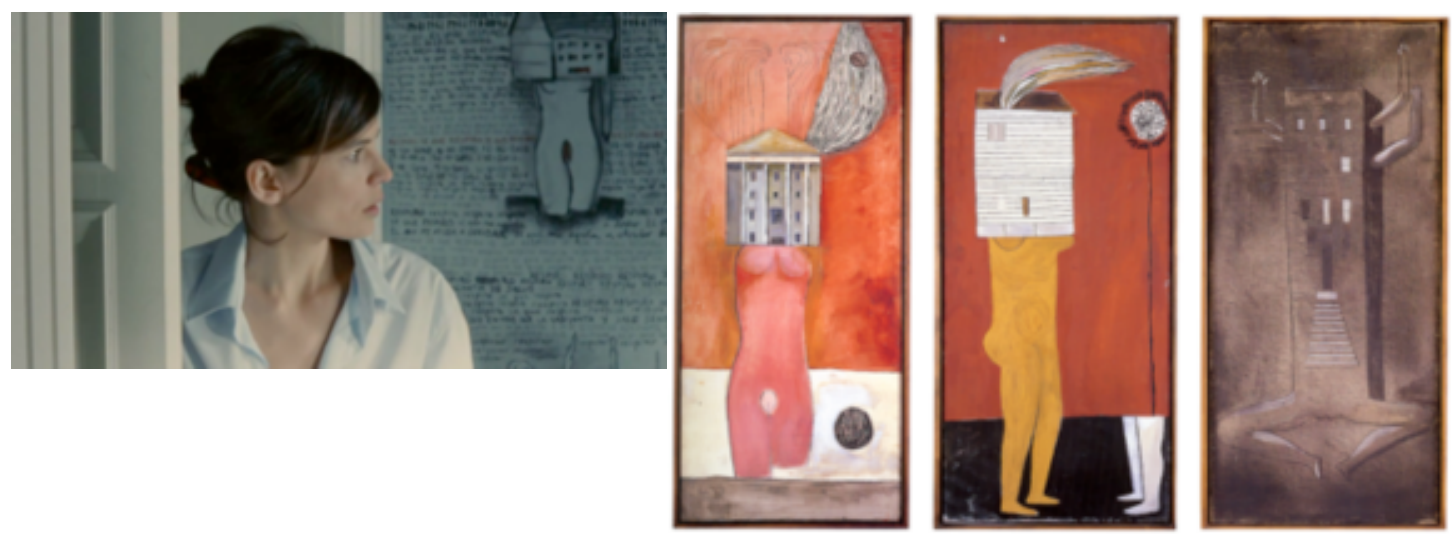

Como señala Poyato (2014, p. 107), estos dibujos "biomórficos [...] en cuya construcción destaca el acusado contraste entre las formas geométricas de la casa ocupando el lugar de la cabeza, y las formas redondeadas de un cuerpo femenino plenamente humano" revelan el doble encierro del que padece Vicente. Primero en la mansión de Ledgard, de la que no podrá escapar pese a sus intentos. Y, en segundo lugar, en su propio cuerpo (representado por la mujer mutilada) ya que "la piel transgénica que le ha sido transplantada se vuelve, para Vera, en el primer lugar de su reclusión, antes de la habitación donde está encerrada" (Thibaudeau, 2013, p. 196).

Así, estas mujeres son casas-cuerpo que recluyen su identidad en un cuerpo que es visible y en el que todo es "tan cerrado, que sugiere antes la entraña que la calle. Y unos lazos afectivos de los que parece imposible escapar” (Fernández Ruiz, 2004, p. 216). Lazos afectivos que se corresponden a sí mismo y que imposibilitan a Vera olvidar su identidad como Vicente para asumir otra nueva, algo concretado en el momento en el que ella besa una foto de Vicente, aparecida en el periódico. De esta forma, puede decirse que en este caso, “el intertexto desempeña [...] una función tautológica, al contribuir, remarcándola, a la caracterización del personaje” (Poyato, 2014, p. 108).

También es en esta identificación de la casa con la mujer que hace Bourgeois, en la que al destacar sus órganos sexuales, ésta se cosifica, anulando la distancia entre mujer y objeto. Así, no es de extrañar que Vera se refiera a sí misma como el juguete de Ledgard, cuando le amenaza con suicidarse si se 
acerca a ella. También es el objeto de deseo del cirujano, que no ha realizado en ella más que una reconstrucción de su mujer fallecida, su réplica viviente.

Sin embargo, McEvelley propone una interpretación diferente de esta serie de Femme-maison. A partir de la iconografía clásica (concretamente, de la Artemisa de Éfeso y de la Virgen María), explica que éstas a veces también tienen, más que una casa, una ciudad (o sus murallas) sobre la cabeza. Así, "el icono de la mujer casa [...] indica a la diosa, o a la hembra, como el fundamento de la comunidad humana” (McEvelly, 2007, p. 340). Esto, aunque seguramente escape al film, en una visión forzada podría leerse como que es Vera quien finalmente se alza con la victoria, quien se sitúa por encima de los demás personajes.

Además de estas dos consideraciones, esta mujer-casa puede tener otra más, dada por la profesora de yoga que Vera ve en la televisión. Ésta hará referencia a la construcción de un lugar interior "en el que os podéis refugiar, al que nadie más tiene acceso [...] en el que encontraréis paz, sosiego, libertad”. Así, la casa que aísla a la cabeza de la mujer del mundo puede verse como una especie de fortaleza exterior, una muralla visible que protege lo invisible de aquello que la pueda herir. El único lugar donde Vera puede sentirse "en casa" y en paz, pues es tan sólo en su interior que sabe que sigue siendo Vicente.

Para concluir, hay un punto más que relaciona a Vera y a la obra de Bourgeois. Las dos crean figuras que están hechas a base de jirones, desgarradas y asexuales. Pero, continuando con este paralelismo, podría verse a Vera como si fuese fruto de la obra de Bourgeois, pues este personaje en sí mismo (por la malla que lleva, por el dolor producido a raíz de su cuerpo mutilado) se asemeja a aquéllos que crea la artista francesa.

La obra de Louise Bourgeois ha sido definida en "la transgresión y en la poderosa presencia de los aspectos físicos, sexuales y corporales. En la exageración y la degradación” (Fernández Ruiz, 2004, p. 205), hecho ya comentado con anterioridad y traducido en la película en una doble capa: transgresión y fuerte presencia del cuerpo físico y de la sexualidad por la 
transformación de Vicente en Vera y, asimismo, en la segunda capa, en las figuras que hace Vera al estilo de Bourgeois.

Asimismo, en cuanto a la escultora "se ha descrito a menudo su obra como autobiográfica: como una manera de distanciar los miedos y resentimientos [...] [Tenía] una fantasía infantil en la que ella y sus hermanos desmembraban a su padre y lo devoraban [...]” (McEvelly, 2007, p. 337).

Si bien en La piel que habito la figura del padre está totalmente ausente (salvo la excepción de Ledgard-Norma), podría comprenderse que Ledgard es, hasta cierto punto, el padre de Vera en cuanto a que ha sido su creador. Y, aun sin llegar a este sueño de canibalismo, el objetivo de Vera sí que es acabar con este padre para poder volver a ser libre.

Pero más que este aspecto del padre, tiene más en común con la consideración del arte como una manera de distanciar los miedos y los resentimientos. Pues el arte puede ser visto en esta película como un calmante para la vida, puesto que Ledgard es un artista del cuerpo, de la piel, medio al que recurrirá para poder cumplir su venganza y aliviar así su odio. Y, por supuesto, para Vera pues ésta se salva de la locura por la escultura, algo que la caracterizará casi desde el comienzo de la película, como ya se ha explicado anteriormente. Además, el propio Almodóvar señala en los títulos de crédito: "Gracias a Louise Bourgeois, cuya obra no solo me ha emocionado, sino que sirve de salvación al personaje de Vera”.

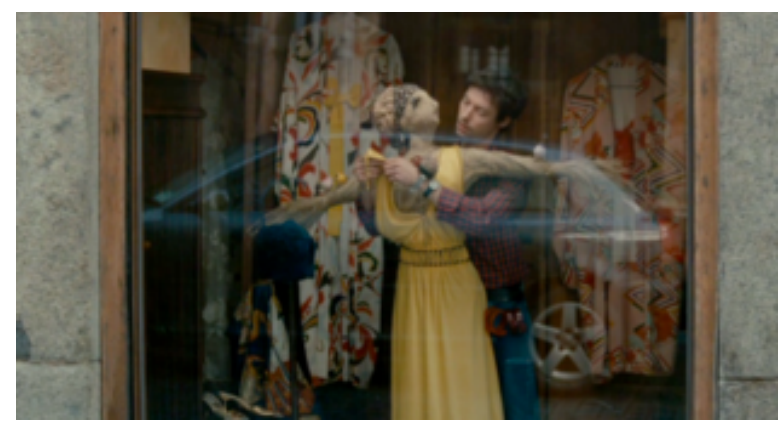

Pero la parte artística de Vera no se desarrolla con ésta, sino que viene de antes. Así, en un fragmento ya comentado, se ve a Vicente ayudando en la tienda de ropa de su madre. Mientras expresa su hartazgo del pueblo, en lugar de vestir a un maniquí lo está transformando, cosiéndole retales de tela. Es decir que, aun antes de ser Vera, Vicente ya exploraba el arte como un modo de salvación. 
Todo esto se concreta en una frase que Bourgeois escribió en la parte alta de Precious liquid (1992): "El arte es una garantía de salud mental". Exactamente igual que hace Vera en su pared, en esta especie de diario en el que escribe sus días de encierro. Esta frase aparecerá entremezclada con otras constataciones como "El opio me ayuda a olvidar" o "Respiro. Sé que respiro". Esto, junto a los dibujos de las posiciones de yoga hacen pensar que son todas las frases que Vera se dedica a sí misma, para no perder la noción de quién es realmente. De esta manera "el gesto creador parece ser, para Almodóvar, lo que persiste de la memoria íntima de un cuerpo cuya apariencia ha desaparecido" (Thibaudeau, 2013, p. 198).

Finalmente, como se viene viendo entre líneas, hay una instancia creadora superior a Ledgard y a Vera, evidentemente no explicitada: se trata del propio Almodóvar. Pues toda la historia representa su universo habitual:

"La piel que habito gira pues en torno a la cuestión del cuerpo y de su territorio, sea éste psíquico, social o fisiológico [...] Constituye así la suma de motivos e interrogaciones sobre la identidad, presentes en toda la filmografía de Pedro Almodóvar, y que parecen alcanzar aquí una suerte de culminación” (Thibaudeau, 2013, p. 194).

Interrogación sobre la identidad sexual que pasa por una inevitable angustia (plasmada en Vera), igual que sucede con la obra de Bourgeois. Así pues, ambos coinciden en este punto: en el objetivo de ir más allá de esta angustia, de no dejarse invadir por ella sino adueñarse de ella y expresarla, como queda representado en Acolchado (1999), en esa mujer que en una posición de tensión realiza un grito hacia el mundo.

\section{La presencia de la pintura y el dibujo}

En La piel que habito las referencias a las artes plásticas no se limitan a las realizadas a Louise Bourgeois, sino que se extienden a muchos más autores. $\mathrm{Al}$ igual que sucede en otras obras, Almodóvar recurre a la pintura que, en ocasiones "será un complemento artístico y en otras se verá implicada en la dramaturgia interna de la narración almodovariana” (Navarrete-Galiano, 2012, p. 75). Es decir, que no son meros elementos decorativos sino que le 
aportan una nueva lectura a la imagen, creando un discurso que juega en diferentes niveles textuales, inscribiéndose en un estilo de cine "para el cual lo fundamental es que detrás de la imagen hay siempre otra imagen” (Marzabal, 1999, p. 20).

En este sentido, Aronica $(2005,59-60)$ señala que "la referencia a textos propios o ajenos puede [...] desempeñar una función tautológica: se trata, en tal caso, de una forma muy efectiva de redundancia con la que se subraya el estado de ánimo de un personaje o un pasaje significativo del relato [...]” como ocurría en el caso anteriormente comentado de las mujeres-casa.

Por otro lado, Aronica continúa exponiendo que "llevada a lo extremo, esta técnica le sirve finalmente al cineasta para adelantar -a modo de flashforward- un momento crucial de la acción que aún no ha tenido lugar (función proléctica)", tal y como se tratará posteriormente.

Estas obras, como también sucede con las de Bourgeois, aparecen por un lado explícitamente (como objeto de decoración) y, por otro, integradas en la puesta en escena (bien en el decorado, bien en la posición de los actores...). Yendo un poco más lejos, Navarrete-Galiano (2012, p. 76) señala que

la filmografía almodovariana supone una conceptualización de la pintura, del arte pictórico, en un soporte audiovisual [...] A fin de cuentas el realizador manchego compone los planos, como si de cuadros "a la manera clásica" se tratara, ya que planifica la disposición de la figuras, los escorzos y puntos de fuga, como lo haría una pintor, y además utilizará el color, con fines narrativos.

En esta línea, Poyato (2014, p. 114) señala la cuidada estética de los planos de Almodóvar, haciendo hincapié en la superficialidad habitual de estos pues, a base de repetir colores en las distintas capas de profundidad, "de puntos de vista elevados $\mathrm{y}$, sobre todo, de fondos muy geometrizados", consigue aplanar la imagen.

En cualquier caso y, como ya se ha dicho, el arte en La piel que habito cobra una importancia fundamental. Pues no solo despierta interés en Vera, que lo considera una garantía de salud, sino también en Ledgard, como se puede concluir a raíz de la cantidad de cuadros presentes en su mansión. Si bien no 
puede definirse quizá como coleccionista de arte, tal y como sucede en el personaje de Ernesto Martel en Los abrazos rotos, los cuadros presentes en esta película dan un nuevo ángulo en la concepción de este personaje: el de Ledgard como artista, en sí mismo. Como señala Almodóvar "la piel es para el doctor Ledgard lo que el lienzo es para el pintor" (Thibaudeau, 2013, p. 201), pues Vera es su obra de arte, que ha trabajado artesanalmente (como demuestra la constante presencia de las agujas, hilos, etc., comentada anteriormente) para conseguir los mejores resultados. Esta concepción de la modificación de un cuerpo como arte queda así mismo plasmada en una breve escena situada hacia el desenlace del film. En dicha escena, uno de los médicos que operó a Vicente va a visitar a Ledgard mientras éste, en un primer plano, se dedica a cuidar un bonsái, cubriendo sus ramas con alambre para que crezcan con esa forma dada. Poco después, el encuadre se va abriendo para mostrar la colección de bonsáis del doctor.

Es en esta estrecha relación entre arte-pintura-modificación del cuerpo en la que tienen cabida todos los cuadros que aparecen en la mansión de Ledgard, puesto que a la par que "hablan del background cultural de Almodóvar [...] le sirven para reflexionar sobre el proceso creativo, a veces incluso con ironía" (Aronica, 2005, p. 60).

En su mayoría estos cuadros son contemporáneos e, incluso, algunos han sido pintados expresamente para la película, en concreto los firmados por Juan Gatti. Habitual colaborador de Almodóvar5, recibió como encargo llevar a cabo una serie de cuadros (titulada Ciencias Naturales) que decorase la casa del doctor Ledgard y cuya temática fuese la anatomía, como señala Navarrete-Galiano (2012).

Dichas obras aparecen en el despacho del doctor, colocadas de forma continua tras el escritorio. De esta manera, durante la conversación anteriormente citada a raíz del comentario sobre los bonsáis con el médico que ayudó a Ledgard en la operación, están en todo momento, aunque nunca se lleguen a ver los tres de forma completa.

\footnotetext{
5 Juan Gatti ha sido el encargado de realizar la mayoría de la estética gráfica de las películas de Almodóvar a partir de Mujeres al borde de un ataque de nervios.
} 
En estas tres obras, pueden verse una primera que representa una cabeza, a medio camino entre músculo y piel de perfil, con los ojos cerrados. En torno a ésta, pueden verse una serie de flores, así como un periquito, a nivel del cuello.

La segunda de ellas es la empleada en un cartel alternativo del film. En ésta, puede verse un cuerpo despojado de piel de espaldas, con las piernas ligeramente abiertas y los brazos extendidos. Al igual que la anterior, la figura humana hecha músculo se encuentra rodeada de motivos naturales: en este caso, se trata de flores, un flamenco y una mariposa.

La tercera y última de ellas, visible solo parcialmente, muestra una mano con los dedos extendidos. Pero una vez más, esta mano no estará cubierta por piel, dejando ver una serie de venas-ramas internas. Esta mano está cubierta a su vez por una serie de ramas que se enredan en torno a los dedos, casi haciendo de la mano una especie de tronco de árbol, rodeado, al igual que en las dos obras anteriores, de flores y mariposas.

Es decir, que las tres obras comparten un motivo similar: el cuerpo humano sin piel, hecho músculo-vena, puesto en relación con la naturaleza.

Rafael Doctor Roncero, crítico de arte y comisario de la exposición de Juan Gatti en la Fresh Gallery de Madrid, encuentra una réplica de estas obras en aquellas ilustraciones del siglo XIX que, realizadas por médicos y científicos, servían para estudiar la taxonomía de las plantas y animales, así como del

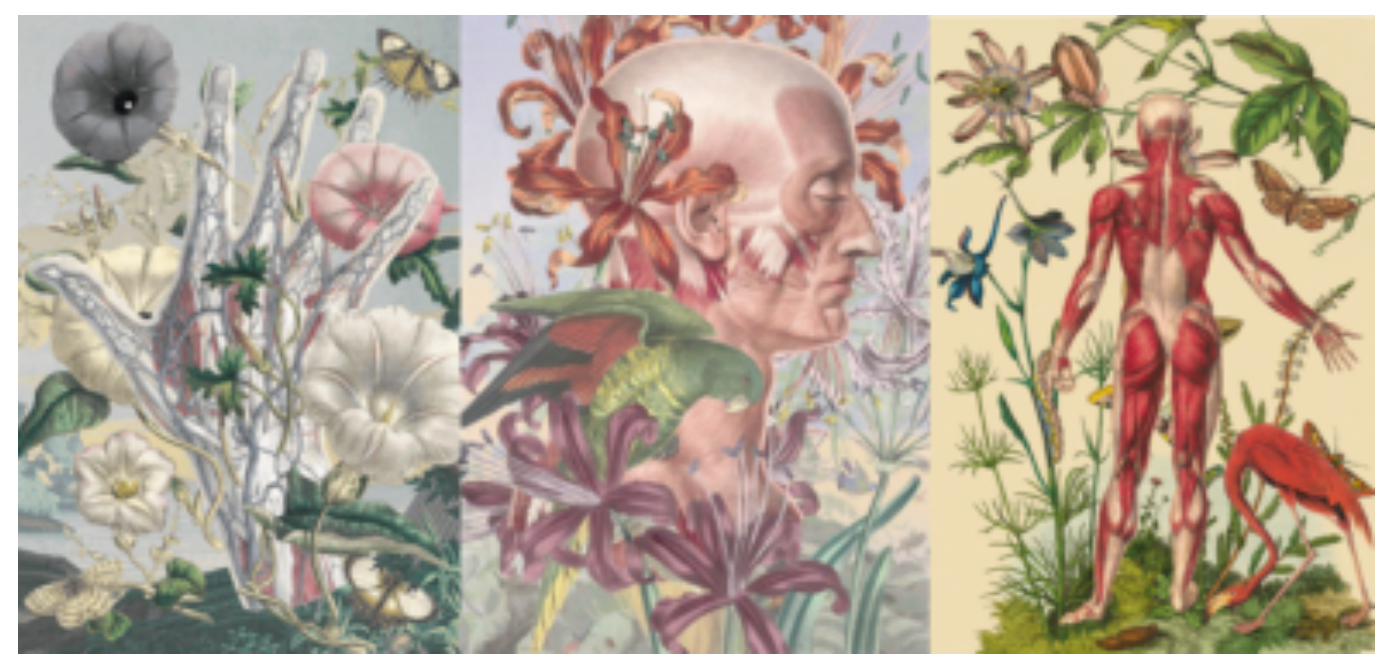

Ciencias naturales (2011) Juan Gatti 
cuerpo humano. Pese a ser concebidas como herramientas para el estudio científico, no discriminaban la parte estética de las composiciones. Así, continúa exponiendo que en Ciencias Naturales esta misma idea de fusionar la estética con la representación del cuerpo humano está presente y que "vemos cómo dialogan las flores o los pájaros con nuestros cuerpos despojados de piel, siendo todo parte de un todo natural que parece ansiar volver a estar de nuevo en comunicación, como reclamando un paraíso siempre perdido" (Doctor Roncero, 2011).

Esta descripción de la obra podría adecuarse a la que se podría hacer del personaje de Vera, entrando en comunión la obra de Gatti y la de Almodóvar. Pues Vera ha sido modificada -despojada de su piel como Vicente-, igual que lo ha sido la naturaleza (en el caso de los bonsáis, como se señalaba anteriormente). Sin embargo, no por ello dejan de estar en armonía con todo lo demás, luchando por "volver a estar de nuevo en comunicación" (Doctor Roncero, 2011): Vera-Vicente vuelve así a la tienda en la que trabaja su madre, buscando recuperar todo aquello que perdió durante su secuestro.

En su análisis de Ciencias naturales, Doctor Roncero (2011) señala asimismo que "todo es bello, pero al mismo tiempo esa belleza es una perversa trampa que nos sitúa en un mundo que nosotros hemos dominado, explotado y destruido, pero al que irremediablemente nos vemos abocados".

Continuando con la analogía anterior, esta descripción podría equipararse igualmente a Vera: creada artificialmente (habiendo destruido a Vicente en el proceso), está dotada no solo de belleza, sino de una piel perfecta. Sin embargo, será esta misma creación lo que le suponga a Ledgard su propio fin: irremediablemente enamorado de su obra de arte, reflejo de su mujer ya fallecida, cae en la trampa de Vera. Es decir, que es la atracción por aquello que ha destruido lo que le lleva a su propia destrucción. O, como señala Thibaudeau $(2013,203)$ "al hacer desaparecer a Vicente y crear a Vera, Ledgard se encerró a sí mismo dentro de un laberinto reflexivo del que no saldrá ileso". 
Finalmente, este crítico de arte concluye exponiendo que

el ser humano está desnudo mientras el resto de seres vivos es capaz de mantener su apariencia exterior. Desposeídos, entablamos una comunión añorada, un ansia de volver a ser lo que los vericuetos de nuestra razón y evolución han impedido. Todo es piel ahora que aparecemos trasparentes y despojados de ella (Doctor Roncero, 2011).

Algo que enlaza con el análisis que hace Thibaudeau (2013) de la relación de la piel del cuerpo humano con el tejido de aquellas ropas que lo envuelven. Como señala a lo largo de su artículo, Vera ha perdido su traje inicial (el cuerpo de Vicente) y ha sido revestida con otro que no se adecua a su yointerno pero que, en vez de destruirlo o anularlo, hace que éste sea capaz de sobreponerse y continuar siendo el mismo yo.

Es decir, que tanto las pinturas de Gatti como La piel que habito, ponen de manifiesto la función de la piel como mero revestimiento exterior de lo realmente importante, natural e inalterable: el propio ser humano, su aspecto interno indestructible, en palabras de la profesora de yoga que Vera escucha. Así, si se despoja al cuerpo humano de lo que lo hace artificial (lo que le hace ser contemplado como el otro) es cuando se puede llegar a establecer esa “comunión añorada” que la evolución ha impedido.

Esta representación no realista del cuerpo humano también queda recogida en otra de las obras presentes en La piel que habito. Dicho cuadro, llevado a cabo por Pérez Villalta y titulado Dionisos encuentra a Ariadna en Naxos (2008), aparecerá en aquellas ocasiones en las que Ledgard espía a Vera por
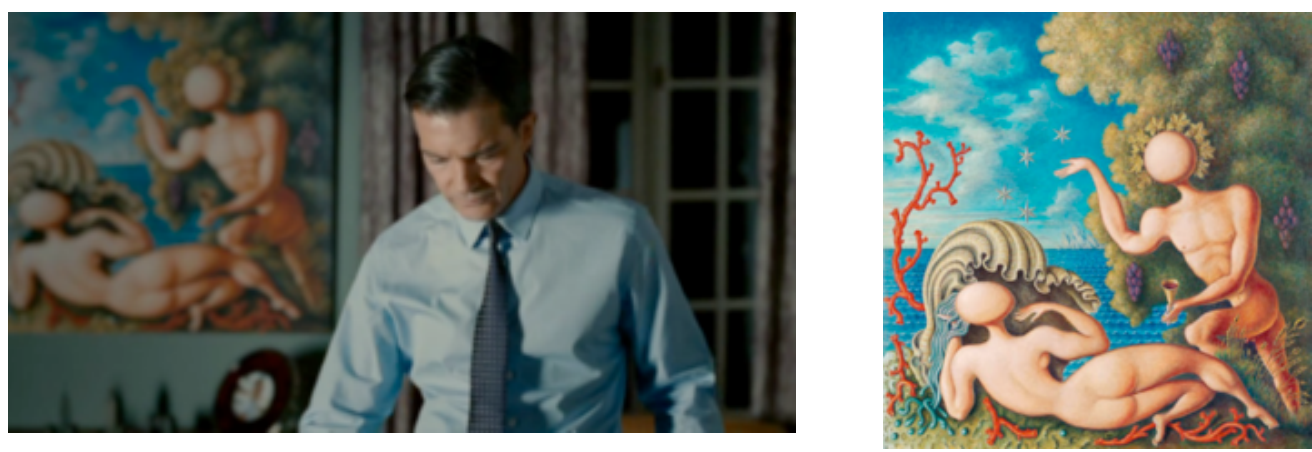

Dionisos encuentra a Ariadna en Naxos (2008), Pérez Villalta 
medio de la cámara que tiene instalada en su cuarto, ya que está situada en la habitación donde el doctor tiene la pantalla. Aparecerá, asimismo, cuando Vera mata a Ledgard en esa habitación.

En esta obra, Dionisos le ofrece una copa de vino a Ariadna, que está tumbada en una posición parecida a aquélla en la que se ve a Vera a través de la pantalla. La segunda vez que aparece este cuadro, será el personaje del cirujano quien tomará la misma postura que Ariadna, tumbado en el sofá que hay frente a la pantalla, en una posición simétrica a la que guarda Vera en ese mismo instante.

Volviendo a la obra de Pérez Villalta, cabe destacar que, al igual que sucede con las obras de Gatti, ambas figuras están rodeadas por la naturaleza, con vegetación por un lado y motivos marinos por otro. Algo que hace recordar asimismo a El nacimiento de Venus de Botticelli, como señala NavarreteGaliano (2012, p. 84). En este sentido, añade que realiza una "clara alusión alegórica al nacimiento de esta nueva mujer, que también es creación de un artista”. Pues, retomando la argumentación anterior de la consideración de Ledgard como un artista, nos encontramos ante el cirujano que observa minuciosamente su obra (en el lento travelling que recorre el cuerpo acostado de Vera). A este respecto, Thibaudeau (2013, p. 202) apunta que

más que una simple pantalla de control [...] ésta se asemeja, por su formato apaisado, sus dimensiones y su localización, a la vez a un cuadro y a un espejo sin azogue por el que Ledgard puede envolver a Vera con la mirada, verla sin ser visto, lo que [...] funda la relación escópica del espectador con la imagen de cine.

Además Almodóvar ha hilado muy fino al escoger el mito de Ariadna, pues éste nos devuelve, según Ovidio en la Metamorfosis, a la idea de la tejedora que pivota por toda la película como vimos antes, e incluso que en su lucha contra Atenea, al ser derrotada por esta diosa, fue convertida en araña, lo que nos lleva de nuevo a Louise Bourgeois.

Pero la identificación no se queda solo ahí: al respecto de Dionisos encuentra a Ariadna en Naxos, al igual que sucede en otras obras de Pérez Villalta, cabe destacar la ausencia de rostros en las figuras humanas. Según el pintor, esto 
es "algo consciente para que haya una identificación mayor del espectador con la obra. Puede ponerle la cara que él quiera" (Cremades, 2010, p. 13). Es decir, una vez más se presenta el rostro como una capa externa, que solo sirve como objeto de diferenciación. A su vez, estos rostros con forma de óvalo casi perfecta, recuerdan a aquellos que aparecen de fondo en la conferencia de Ledgard sobre el transplante de piel y la cirugía estética como forma de recuperar un rostro perdido, así como a los de los figurines presentes en la tienda de ropa de la

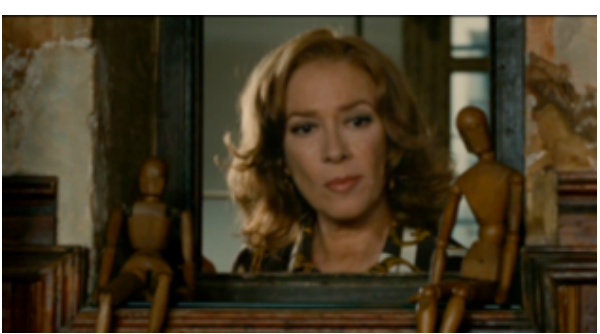
madre de Vicente.

En este lugar privilegiado que se le otorga a la pintura en este largometraje, cobra importancia una figura que ya se ha comentado anteriormente: la de la Venus. Implícito en la obra de Pérez Villalta, queda explicitado en La Venus de Urbino (1538) de Tiziano, situada en las escaleras de la mansión al lado de otra obra del mismo pintor: Venus recreándose en la música. Venus, presentada como símbolo erótico y sexual, "es algo que planea a lo largo de toda la trama argumental de la creación almodovariana" (Navarrete-Galiano, 2012, p. 84).

De esta manera, los cuadros no solo quedan citados, sino que se ponen en relación directa con los personajes: por un lado, como símbolo, pues Vera, envuelta en su body color carne, es presentada como una mujer que suscita el deseo de Ledgard. Y, por otro, plásticamente puesto que ambos personajes toman la postura de estas obras.
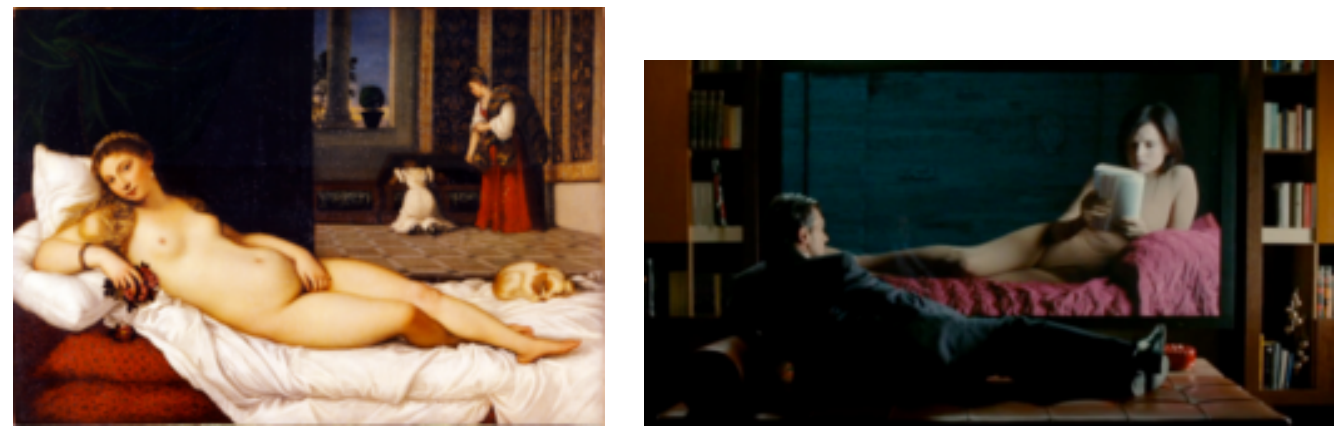

Venus de Urbino (1538), Tiziano 
Así, como se señalaba antes a propósito de Dionisos encuentra a Ariadna en Naxos, Vera aparece tumbada en una ocasión frontalmente, enmarcada por los límites de la pantalla y recordando, como también se ha comentado, a un lienzo. Así, Ledgard contempla a Vera igual que un espectador contempla la Venus de Tiziano: por tanto, podría decirse que la obra italiana condiciona prácticamente el encuadre y la dirección escénica propuesta por Almodóvar.

Pero la relación entre estas obras no se queda aquí; como sucede en Carne trémula (donde aparece una Danae también de Tiziano), el cuadro entra en juego con la trama de la película, dándole una nueva dimensión. Así, en Carne trémula, se introduce el tema de las piernas mientras los protagonistas hablan de una vez que se acostaron. En La piel que habito, serán las piernas de la Venus recreándose en la música las que ocupan la parte superior del encuadre en los planos en los que Zeca viola a Vera,
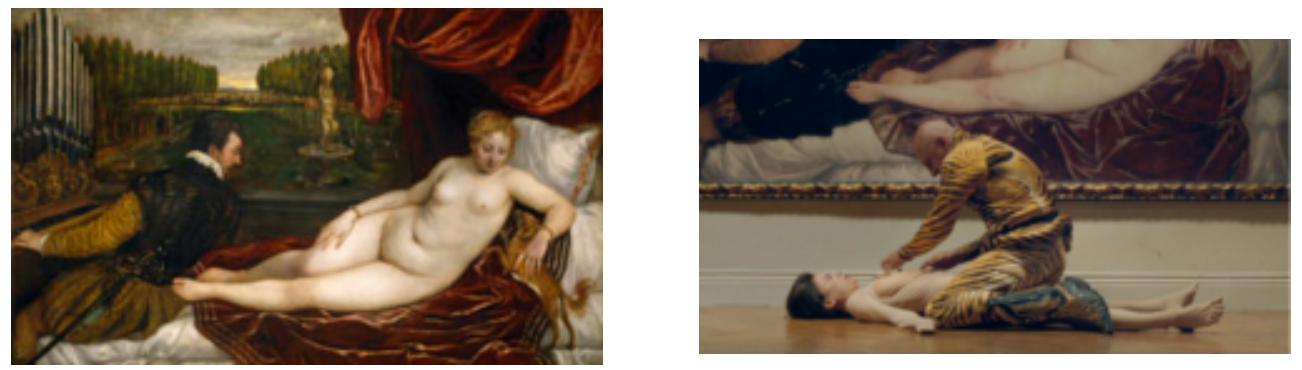

Venus recreándose en la música (1550), Tiziano

acontecimiento que, en palabras de Thibaudeau (2013, p. 202), "remite a la vez a lo grotesco y a la violencia originarios y propios de la mitología grecolatina" y que recuerda la función de estos cuadros de equiparar la imagen fílmica a la pictórica, incluyéndose en la tradición de los desnudos clásicos -que encuentran su eco en Vera ataviada con el body-.

Estas alusiones explícitas a la Venus remiten a su vez a otros cuadros que no

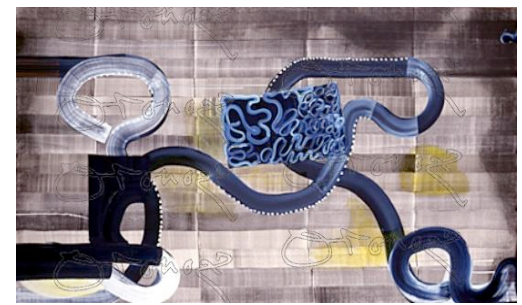

Perdidos en Candem (1999), J. aparecen como citas, sino como una especie de tableaux-vivants, al igual que sucedía con algunas de las obras de Bourgeois. En este caso, bien podría tratarse de la Venus del espejo, de Velázquez que, junto a los dos cuadros de 
Tiziano "manifiestan el hechizo que la criatura ejerce sobre su creador y, más allá, sobre el espectador" (Thibaudeau, 2013, p. 202) o, incluso, de La maja desnuda de Goya.
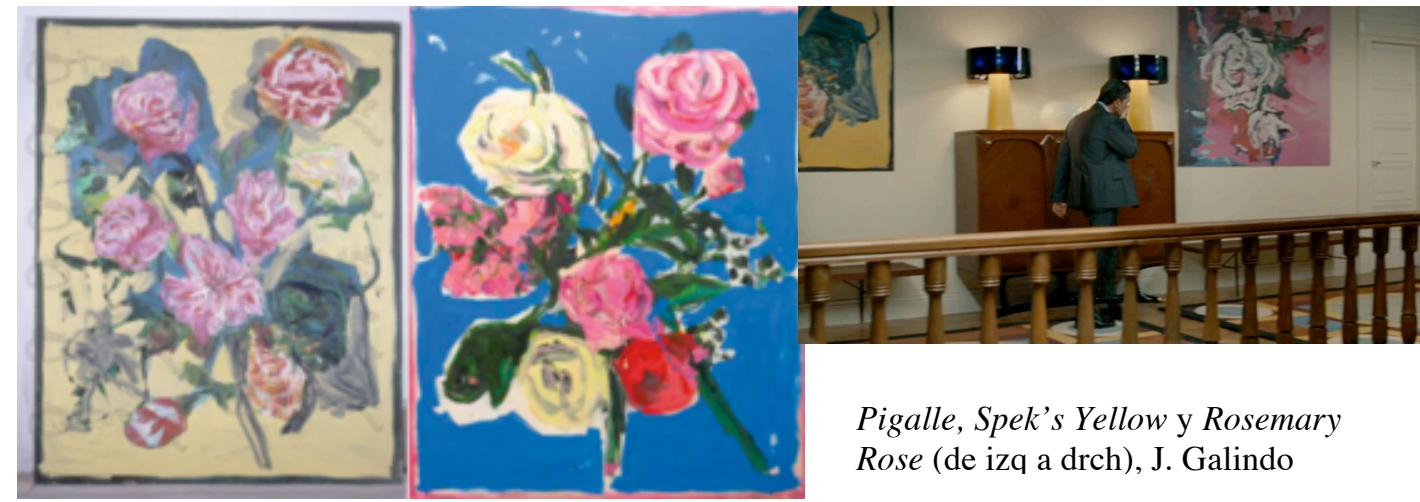

Pigalle, Spek's Yellow y Rosemary Rose (de izq a drch), J. Galindo

Junto a todos estos cuadros, aparecen otros con motivos florales de Jorge Galindo. En concreto, Pigalle, Rosemary Rose y Spek's Yellow, situados en la escalera, en la pared contigua a aquélla en la que se encuentran los de Tiziano. Asimismo, hay un cuadro de Juan Uslé, Perdidos en Candem, situado en el despacho de Ledgard frente a la obra de Gatti.

Paisagem com ponte de Tarsila do Amaral, aparece en el flash-back en el que Marilia narra la historia de Gal y Ledgard. Así, mientras ésta se levanta al oír a su hija cantar, con la piel devastada por las quemaduras causadas por el accidente, puede verse este cuadro entre

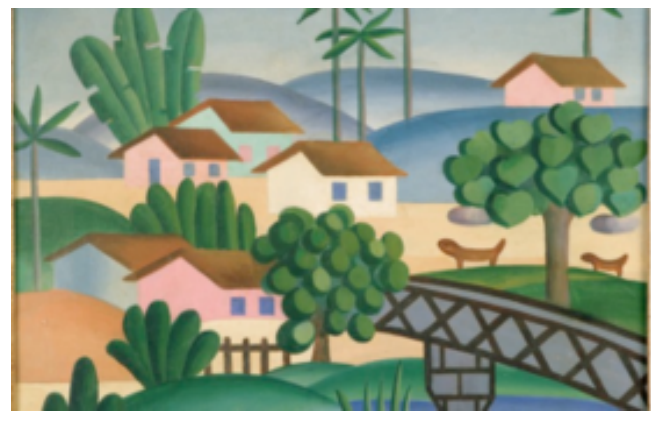

Paisagem com ponte(1931), T. do Amaral las sombras, contrastando el colorido de éste con la escasa iluminación destinada a Gal, que queda como un perfil oscuro recortado en el cuadro.

Otras dos obras que aparecen son Memories of Olive de Alberto Vargas, que representa a una mujer semidesnuda oliendo una flor y que está situada en la habitación de Ledgard, al lado de la cama; y Naranjas y limones, de Julio Romero de Torres, cuadro en el que aparece una mujer sosteniendo algunas naranjas. 


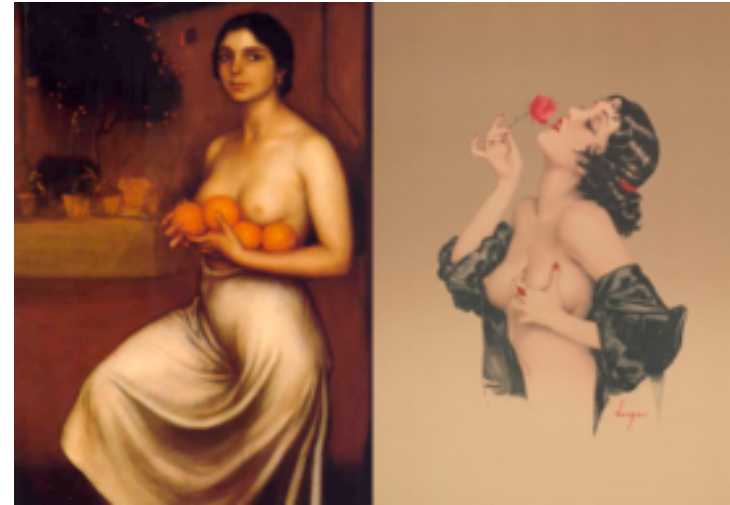

Izquierda: Naranjas y limones (1927),

J. Romero de Torres

Derecha: Memories of olive (1920), A.

Vargas

Hay otros cuadros con los que se establece, según la tipología establecida por Genette, una relación de metatextualidad. Tal es el caso del arte abstracto en general, y lo que podría ser a Jackson Pollock en particular, como señala Navarrete-Galiano (2012). Así, cuando Vicente acaba de ser prácticamente transformado en Vera y recibe algunos vestidos, se dedica a romperlos y tirar los jirones por todo el suelo del cuarto, salpicando el gris de éste con los colores de la tela, que recoge uno por uno. A su vez, la colcha (que puede verse al completo en esta escena gracias a un plano cenital), sobre la que Vera se sube y coloca los vestidos antes de empezar a romperlos, recuerda a algunas de las obras de Juan Uslé.

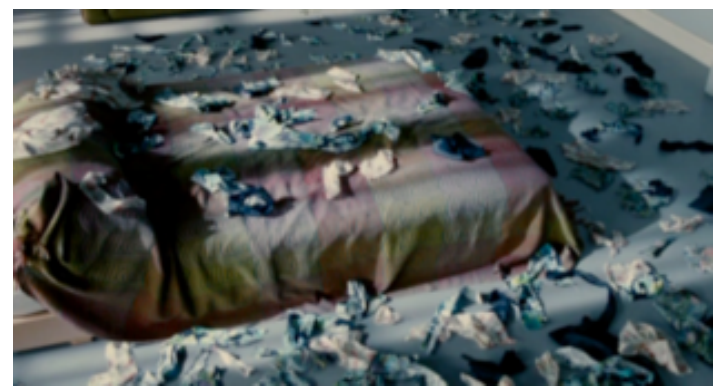

Jirones de tela en el cuarto de Vera

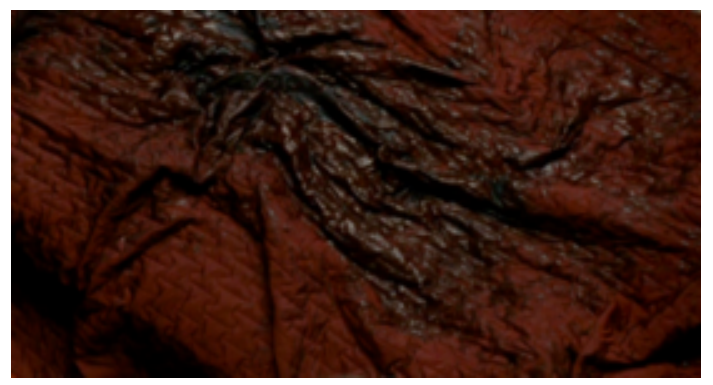

Sábana manchada de sangre

$\mathrm{Y}$, al igual que sucede en Los abrazos rotos con una cortina, se emplea un plano ocupado por completo por la colcha roja en la que Ledgard ha matado a Zeca, manchada con la sangre de éste, para dar pie a lo que parece ser un cuadro abstracto. 


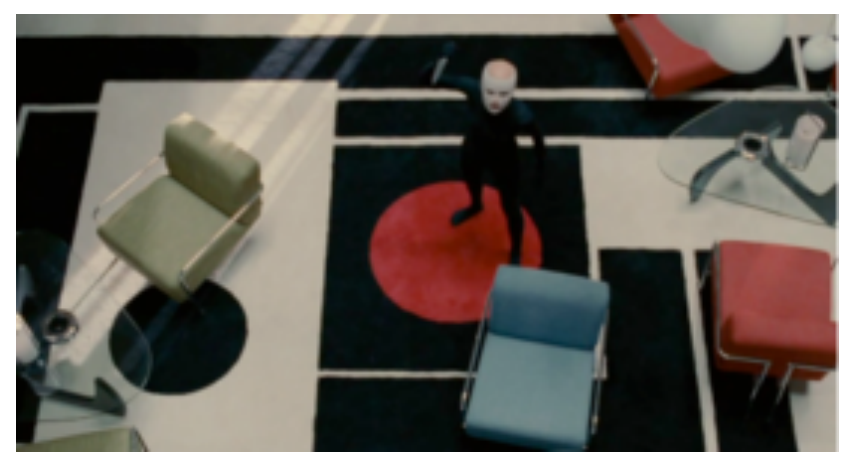

Por otro lado, la constante geometría de los planos del film -la alfombra, los planos en los que Ledgard prepara las pruebas en el laboratorio, usando cristales con formas geométricas, etc.-, recuerda al constructivismo ruso en general y, más concretamente a Kandinsky.

Por su parte, Navarrete-Galiano (2012, p. 82) señala que "el primer plano de la película, la vista de Toledo, recuerda a muchos cuadros costumbristas que reflejan la capital castellana, o incluso podría tener como referencia la visión que dio El Greco de la ciudad.”

Así, teniendo en cuenta la presencia de autores que van desde el clasicismo de Tiziano hasta una serie de autores con un estilo moderno e, incluso, tendente al abstraccionismo, podría concluirse con Aronica $(2005,58)$ que el cine de Almodóvar

aglutina en su discurso motivos procedentes de la cultura alta y popular, contemporánea y tradicional, demostrando una capacidad innata de poner en relación lo viejo con lo nuevo en un imparable proceso combinatorio que afecta a todos los niveles textuales, tanto de la forma como del contenido.

Finalmente y, quizá al margen de lo que puede ser considerado como "arte", Thibaudeau remarca la similitud del muro que pinta Vera con lo que ella denomina como "arte bruto". Así, evoca por un lado, el caso de Fernando Oreste Nannetti quien "grabó durante nueve

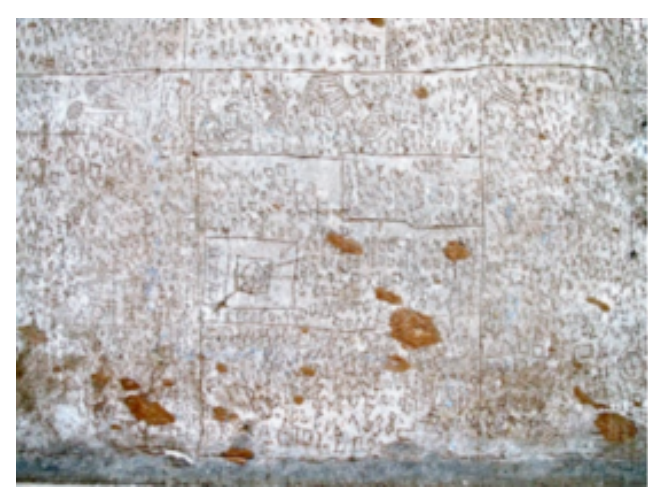
años, con la punta de la hebilla de su chaquetilla, las paredes del hospital psiquiátrico de Volterra (Toscana) donde estaba internado" y, por otro el de "Jeannot, campesino de Béarn (Francia), quien grabó con un punzón en letras mayúsculas el suelo de madera de la habitación donde él mismo se había encerrado" (2013, p. 199). 
De esta manera, una vez más, se llega a la conclusión de que en el film se toma el arte como la única forma de salvación del yo. Es por esto por lo que la inunda, tanto como elemento decorativo (en la mansión de Ledgard), como de "apropiación de[1] encierro" (Thibaudeau, 2013, p. 200) (en las emulaciones de Vera al arte de Bourgeois), como elemento simbólico (la elevación de la cirugía y de la supervivencia a la categoría de arte).

\section{Otras referencias al arte: literatura, escultura, video-arte...}

La inclusión de obras de arte en La piel que habito no solo se concreta en la pintura, sino que se extiende a muchas otras formas de expresión. En este sentido, Navarrete-Galiano (2012, p. 85) pone de manifiesto que el arte envuelve también el mobiliario, como la alfombra inspirada en el movimiento constructivista ruso o las mesas que hay en el salón, en la obra de Isamu Noguchi.

Pero además de estas mesas, hechas de cristal y acero, con forma de triángulo de puntas redondeadas, podrían verse otras referencias al artista estadounidense-japonés. En el mismo salón en el que se pueden ver estas mesas, al fondo, sobre un mueble pueden verse dos esculturas con formas redondeadas, así como un candelabro hecho en metal, a base de cuadrados. Estas formas geométricas hacen pensar en obras tales como Octetra o Red Cube.

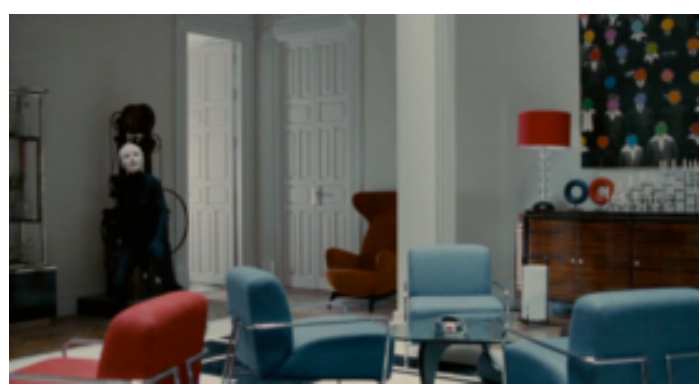

La obra de Isamu Noguchi en La piel que habito.
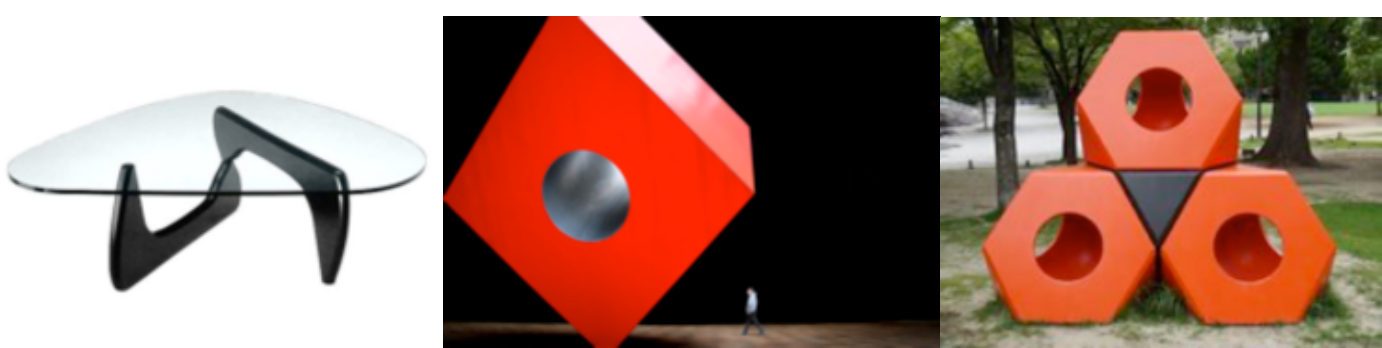
Otra forma de arte que puede verse, de forma sutil, es el video-arte. Así, mientras Vera ve por primera vez la televisión, una de las cadenas emite Endless not de Oscar Shocking: primero, unos cuantos planos que muestran el cuerpo tumbado del artista, luego, Vera cambiará de cadena y volverá sobre esta para ver cómo el chico se pone una corona.

En esta video-creación, se muestra el paso del artista por diversos espacios pertenecientes a una ciudad, caminando bajo una corona que él mismo se pone. A propósito de ésta y de Nurse Bound, Brenda Chávez escribe que representa

un lugar a veces hostil donde uno no se reconoce; a veces tan fértil que permita reencontrar la imagen perdida [...]. Emociones encontradas que luchan por descansar allí donde poder comenzar de nuevo, donde cicatrice el dolor, la ansiedad, el miedo, donde aprender a no sentir el miembro amputado de una vida que ya no será la misma, para bien y para mal.

Así, si bien no se hace más referencia a esta obra en La piel que habito, no viéndose siquiera íntegramente, su significado se encuentra en la línea temática del film, ya que se cuestiona sobre la identidad en un momento en el que el pasado ha cambiado radicalmente, dejando el futuro en la incertidumbre y el presente como un lugar extraño, desconocido para uno mismo.

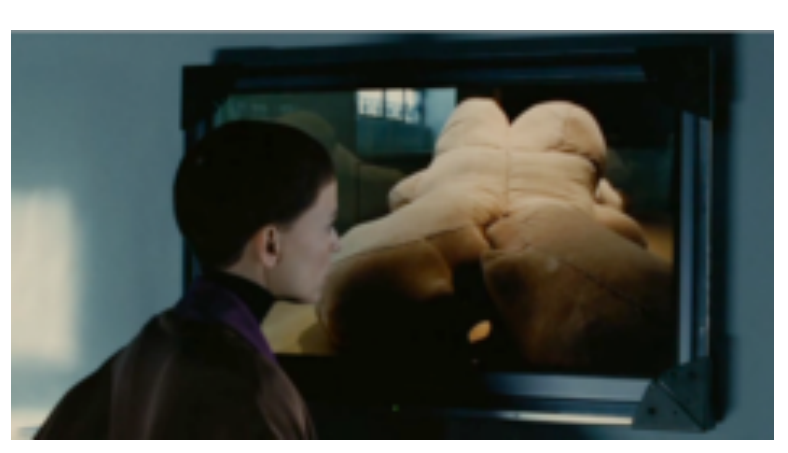

Esta video-creación aparece junto a otros clips. Uno de ellos, grabado para la película, es el de la profesora de yoga. Este inserto, llamará la atención de Vera hasta el punto de determinar su comportamiento pues la

profesora expresa que hay un lugar al que solo uno mismo puede acceder, independientemente de la forma que lo envuelva, como se comentaba a propósito de las mujeres-casa de Bourgeois. Artista que, por otro lado, conocerá gracias a la televisión: será la segunda vez que se siente frente a la pantalla cuando vea un fragmento del documental realizado por Marion 
Cajori y Amei Wallach titulado The spider, the mistress and the tangerine (2008). En ausencia de sonido, la grabación de estas obras de arte llama tanto la atención de Vera que ésta se levanta para observar la pantalla más de cerca, algo que dota a la pantalla de una cierta fisicidad. En esta línea, como señala Thibaudeau (2013, p. 203) "estas pantallas de plasma [...] nos permiten establecer una analogía entre la pantalla y la piel, un paralelismo entre lo visual y lo táctil”. Pues son las pantallas (al igual que los cuerpos) los que dan a conocer una realidad ajena al yo por medio de una superficie, de una imagen.

Y, finalmente, el vídeo que aparece en la tercera cadena que Ledgard permite ver a Vera, pertenece a la serie de Living Edens de la National Geographic. Los fragmentos que aparecen, de Ngorongo por Alejandro de Pablo, muestran a un cervatillo que sale huyendo de su captor, un guepardo. Con un cambio de canal, se pasa a la profesora de yoga, luego, a la video-creación y, finalmente, de vuelta al vídeo de National Geographic, en el que el guepardo ha conseguido a su presa.

Es decir, que en la televisión puede verse una especie de analogía del estado de Vera; por un lado, el de presa que, al igual que el cervatillo, intenta huir inútilmente (en moto, siendo Vicente) de su captor. Por otro, de pérdida de la identidad en el presente, venida de la interpretación de Endless not y de la ambigüedad sexual y los cuerpos deformados de Bourgeois. $\mathrm{Y}$, finalmente, las enseñanzas de la profesora de yoga, la cual destaca el aspecto inmune del yo interior, de la verdadera identidad pese a los cambios que puedan venir del exterior.

Además de estos, hay otros dos vídeos que han sido insertados en La piel que habito pero, esta vez, a modo de imágenes de archivo. Una de ellas es la que ilustra la narración de Marilia sobre la historia de Zeca, en la cual puede verse un chico bajando unas escaleras de una favela. La otra, presente también en esta escena, es la del coche ardiendo (de Ledgard y Gal), tomada de Corbis / Latinstock. 
Volviendo a las citas y dejando atrás las artes plásticas, en La piel que habito no son pocas las obras literarias que se dejan ver entre sus planos. Al igual que sucede en el libro del que procede, Vincent-

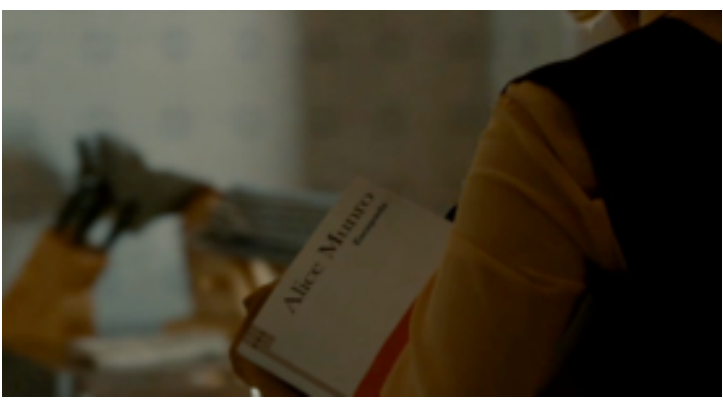
Vicente encuentra en la lectura una forma de entretenimiento durante su cautiverio. Si bien en Tarántula se tratan de grandes clásicos, en la película estos son cambiados por obras, en su mayoría, más contemporáneas. Y no será tanto Vicente el que lea como Vera, pues no solo hay varios planos en los que ella aparece concentrada en un libro, sino que en su cuarto puede verse una torre hecha con novelas apiladas, algo que es también una marca Almodóvar, tal y como se ve, por ejemplo, en La flor de mi secreto (1995), para construir a sus personajes (Gómez, 2014, 74-77).

Así, casi al comienzo del film, Marilia le lleva el desayuno a la cautiva junto a un libro: Escapada de Alice Munro. Para Almodóvar, como declaró en su blog en 2013, esta escritora es la mejor relatista en lengua inglesa. Este libro, Escapada, está compuesto por ocho relatos, de los cuales tres están destinados a narrar la historia de Juliet, en tres etapas de su vida diferentes. En la primera, acude al encuentro de un amor presentido; en la segunda, juzga a sus padres una vez que ella es madre y, finalmente, en una tercera es abandonada por su propia hija.

El segundo libro en aparecer es Un ángel en mi mesa, la autobiografía de Janet Frame. En este libro se narra cómo fue tachada de loca, siendo enviada a diferentes hospitales psiquiátricos y se autodescribe como alguien "tan asexual como un palo de madera”.

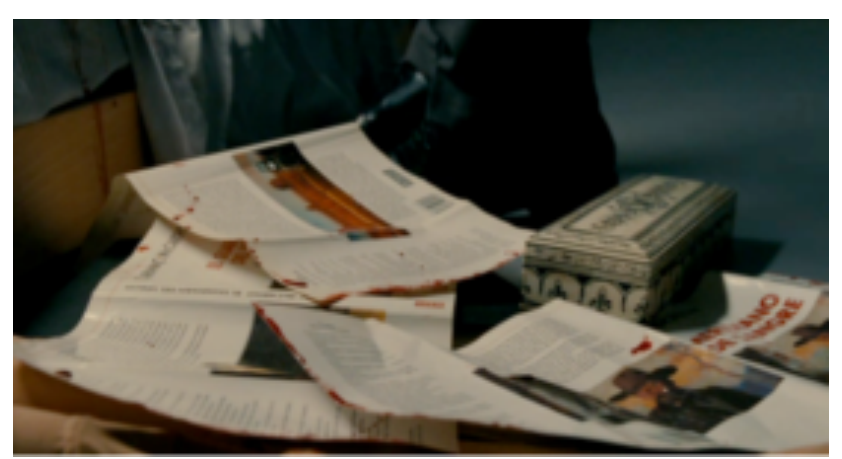

Los otros libros identificables que aparecen son Meridiano de sangre, Ciudades de la llanura y El guardián del vergel, todos de Cormac McCarthy. Las portadas de 
dichos libros aparecen manchadas de sangre, tras el primer intento de suicidio (en el orden de la proyección del film, no en el orden cronológico) de Vera. Creyendo Ledgard que ésta está dormida, entra en su habitación, para encontrársela llena de cortes en las muñecas y en los pechos. El doctor la levanta de la cama para llevarla corriendo al quirófano y coserle las heridas. En toda esta acción, hay un inserto de un detalle de las portadas anteriormente citadas de Cormac McCarthy, tiradas en el suelo, unas sobre otras, y con los bordes cubiertos de sangre pues ha sido con éstas con las que Vera ha conseguido cortarse. De entre estas tres, el título más legible es el de Meridiano de sangre, obra que parece guardar en este caso más relación con la escena por el título que por la trama ya que se trata de una especie de western.

Siguiendo a Sánchez-Mesa, puede afirmarse que estos intertextos literarios, sobre todo en el caso de McCarthy y Munro actúan como una especie de anticipo, pues revelan que "ella [Vera] desde el principio se está preparando para vengarse y para huir" (2014, pp. 176).

Finalmente, el último libro cuyo título aparece nítido es el de El gen egoústa (subtitulado en español como Las bases biológicas de nuestra conducta), de Richard Dawkins. Pero esta vez no será Vera quien lo lea, sino Ledgard. Este libro, que aparecerá en la escena inmediatamente anterior a la que se acaba de comentar, también tendrá un plano reservado para él: tras llegar Ledgard a la mansión, deja su chaqueta y se aproxima a una mesa para coger un mando a distancia. La cámara acompaña este movimiento con un rápido travelling, que se detiene para mostrar la mano de Ledgard cogiendo el mando, situado justo al lado de El gen egoísta.

Según el propio Dawkins, este libro "debiera ser leído casi como si se tratase de ciencia-ficción. Su objetivo es apelar a la imaginación. Pero esta vez es ciencia [...]". Tras estas frases, afirma su siguiente tesis: "somos máquinas de supervivencia, vehículos autómatas programados a ciegas con el fin de preservar las egoístas moléculas conocidas con el nombre de genes" (1993, p. 4). Para Dawkins, el egoísmo podría verse como una especie de metáfora con la que queda explicada que la supervivencia de un gen depende de su 
capacidad de adaptarse al medio, al igual que Darwin exponía a nivel del individuo en su teoría de la selección natural. Es decir, que Vera (tanto como individuo como experimento), se encuentra bajo el peso de esta definición: Vicente solo podrá sobrevivir si se adecua al nuevo medio que, en este caso, es un cuerpo de mujer. De ahí que se vuelva esa máquina de supervivencia que es Vera, que "aprende a vivir dentro de la piel que habita" y haciendo de La piel que habito una historia sobre la "capacidad de resiliencia" (Lameiras, 2013, pp. 148-149).

Concluyendo este apartado, cabe decir que todos los autores literarios que aparecen son escritores de cierto renombre ${ }^{6}$, dando a la cultura tanto de Vera como de Ledgard un cierto carácter elitista. A este respecto, el director manchego ha declarado que le resulta muy importante lo que leen sus personajes protagonistas (El Huffington post, 2013) pues, en gran parte, guarda relación con la trama.

\section{Conclusiones}

La piel que habito está envuelta en todo un tejido de referencias que permiten crear una serie de niveles de lectura de la película, ofreciendo una lectura más rica en matices conforme más se ahonde en dichas capas.

En el análisis que aquí nos ocupa y, sobre todo en lo que respecta a la obra de Louise Bourgeois, todo el entramado de obras de arte que envuelve a la película sirve para darle a los personajes una dimensión narrativa más amplia, enfatizando ciertos aspectos de su personalidad que tan solo resultarían perceptibles al espectador que conociese estas referencias. Referencias que son muy diversas (literatura, pintura, dibujo, escultura...) pero que encuentran el nexo común del arte como garantía de la salud mental, como una especie de forma salvadora frente a lo destructor de la "realidad” que envuelve a los personajes.

\footnotetext{
${ }^{6}$ Munro obtuvo el Nobel de literatura en 2013, dos años después del estreno de La piel que habito; McCarthy fue ganador del Premio Pulitzer en 2006 por La carretera y las teoría de Dawkins fueron posteriormente estudiadas.
} 
También, por otro lado actúan en una relación que podría denominarse como icónica de la situación de Vera. Las mujeres-casa de Bourgeois expresan su encierro; las esculturas que hace a semejanza de ella junto a su body ponen de manifiesto su sexualidad ambivalente y su sufrimiento interior debido a la mutilación de su cuerpo, lo que da pie a una nueva sexualidad (o presexualidad); Escapada de Alice Munro presagia las intenciones de Vera...

Pero la utilización de estas obras no solo deja ver una declaración de intenciones por parte de Vera e, incluso, de Ledgard (siendo entonces puramente diegética) sino por parte del propio Almodóvar, en una especie de toma de posición frente al proceso creativo. Pues estas referencias al arte (que no son exclusivas de La piel que habito sino una constante extrapolable a toda su obra) se encuentran en la propia puesta en escena, determinándola en muchas ocasiones, haciendo ecos a ciertos cuadros o esculturas mediante la posición de los personajes.

\section{Referencias bibliográficas}

Aronica, D. (2005). "Intertextualidad y autorreferencialidad: Almodóvar y el cine español”. En Zurián, F.A. y Vázquez Varela, C. (coord.). Almodóvar: el cine como pasión, actas del Congreso Internacional "Pedro Almodóvar: Cuenca”. Cuenca: Universidad de Castilla-La Mancha. $1^{\mathrm{a}}$. Ed. Págs. 57-80

Chávez, B. (sin fecha) Oscar Shocking [en línea]. Disponible en: http://www.oscarshocking.com/ [Fecha de consulta: 24/05/14]

Cremades, J. (2010). "Entrevista: Guillermo Pérez Villalta, rendido al placer y a la belleza”. Tendencias del arte. Num. 35, pags 10-13.

Dawkins, R. (1993). El gen egoísta. Barcelona: Salvat.

Doctor Roncero, R. (2011). Juan Gatti: Ciencias Naturales (del 28 de noviembre a enero de 2013) [en línea]. Centro cultural de España en Buenos Aires. Disponible en: http://www.lafreshgallery.com/webfresh.nsf/pgeExpoAnt?OpenPage\&E xpandSection $=23 \% 2 \mathrm{C} 21 \% 2 \mathrm{C} 20 \#$ Section23 [Fecha de consulta: 25/05/14]

Eco, U. (1999). La estrategia de la ilusión. Barcelona: Editorial Lumen.

Fernández Ruiz, B. (2004). De Rabelais a Dalí: la imagen grotesca del cuerpo. Valencia: Universitat de València.

Genette, G. (1982). Palimpsestes: la littérature au second degré. Paris: Éditions du Seuil. 
Gómez Gómez, A. (2014). "Del autorretrato a una cierta autobiografía”. En Poyato, P. (ed.). El cine de Almodóvar. Una poética de lo "trans". Sevilla: Universidad Internacional de Andalucía, 1o. Ed. Pág. 53-80.

Marzabal, I. (1999). Wim Wenders. Madrid: Cátedra.

McEvilley, T. (2007). De la ruptura al "cul de sac": arte en la segunda mitad del siglo XX. Tres Cantos (Madrid): Akal.

Metz, C. (1971). Langage et cinéma. Paris: Larousse.

Museo Guggenheim. (Sin fecha). Mamá, de Louise Bourgeois [en línea]. Disponible en: http://www.guggenheim-bilbao.es/obras/mama-2/ [Fecha de consulta: 24/05/14]

Navarrete-Galiano, R. (2012). "La piel que habito: nueva creación literaria, pictórica y escultórica de Almodóvar”. En Crespo Fajardo, J. L. (coord.). Arte y cultura digital. Planteamientos para una nueva era. Málaga: Grupo de investigación Eumed.net. Págs 74-86.

Poyato, P. (2014) “Presentación”. En Poyato, P. (ed.). El cine de Almodóvar. Una poética de lo "trans". Sevilla: Universidad Internacional de Andalucía, $1^{\circ}$. Ed. Pág 12.

Poyato, P. (2014) "La escritura del "almodrama”. En Poyato, P. (ed.). El cine de Almodóvar. Una poética de lo "trans". Sevilla: Universidad Internacional de Andalucía, $1^{\circ}$. Ed. Págs. 99-124

Sánchez-Mesa, D. (2014). "Plasticidad de la identidad 'Ciborg' en La piel que habito. En Poyato, P. (ed.). El cine de Almodóvar. Una poética de lo “trans”. Sevilla: Universidad Internacional de Andalucía, $1^{\circ}$. Ed. Págs 169-193.

RTVE.es/EFE. (2012) "La casa encendida celebra sus 10 años con una gran muestra sobre Louise Bourgeois". Publicado el 18/10/12 [en línea]. Disponible en: http://www.rtve.es/noticias/20121018/louisebourgeois-exorciza-temores-gran-muestra/570908.shtml [Fecha de consulta: 24/05/14]

Thibaudeau, P. (2013). "El cuerpo, la piel y la pantalla: los territorios habitados por Pedro Almodóvar" [en línea] Fotocinema: revista científica de cine y fotografía. Num. 7, págs 192-208. Disponible en: http://www.revistafotocinema.com/index.php?journal=fotocinema\&p age $=$ article\&op $=$ viewFile\&path ${ }_{5} \mathrm{~B} \% 5 \mathrm{D}=198 \&$ path ${ }_{5} \mathrm{~B} \% 5 \mathrm{D}=133$

[Fecha de consulta: 4/06/2014]

Thibaudeau, P. (2013a). "Esperando a Vera: la metamorfosis del sujeto en "La piel que habito" de Pedro Almodóvar". Ámbitos. Revista de Estudios de Ciencias Sociales y Humanidades, nº 30, págs. 41-47.

Cómo citar: Parés Pulido, M. (2014). "Intertextualidad en La piel que habito: pintura, escultura y dibujo". Fotocinema. Revista científica de cine y fotografía, 9, pp. 325-361. Disponible:

http://www.revistafotocinema.com/index.php?journal=fotocinema 